\title{
Investigation of the Elements of the History of Mathematics in Secondary School Mathematics Coursebooks
}

\author{
Satı Ceylan \\ Ministry of National Education, İhsan Erturgut Middle School, Manisa/Turkey (ORCID: 0000-0002-3376-1709)
}

Article History: Received: 10 March 2020; Accepted: 2 January 2021; Published online: 31 January 2021

\begin{abstract}
This study investigates the use of the history of mathematics in secondary school mathematics coursebooks designed according to the new curriculum prepared in 2018 and to make alternative suggestions in which mathematics history can be used. For this purpose, four mathematics coursebooks, which were decided to be taught in schools affiliated to the Turkish Ministry of National Education for four years as of 2018, were analyzed by document analysis method, and this research attempted to determine to what extent the history of mathematics was used in these coursebooks. While making this analysis and analyzing the data, the categories proposed by Erdoğan et al. (2015) were used, including "historical notes," "notes on usage areas of mathematics," "applications with historical notes," and "historical elements in students" extracurricular activities." As a result of the study, it was found out that the 27 elements of the history of mathematics used in the coursebooks were mostly included at the fifth grade, in the lead-in stage, in the area of learning numbers and operations, in the form of small historical snippets about the historical development of situations other than mathematics. In light of these findings, it can be suggested that the history of mathematics is not used sufficiently in secondary school mathematics coursebooks.
\end{abstract}

Keywords: Mathematics coursebooks, history of mathematics, mathematics education

DOI:10.16949/turkbilmat.701479

Öz: Bu çalışmanın amacı 2018 yılı öğretim programına göre düzenlenmiş ortaokul matematik ders kitaplarında matematik tarihinin kullanılma durumunu incelemek ve matematik tarihinin kullanılabileceği alternatif önerilerde bulunmaktır. Bu amaç doğrultusunda, 2018 yılı itibariyle dört yıl süreyle milli eğitim bakanlığına bağlı okullarda okutulmasına karar verilmiş dört matematik ders kitabı doküman analizi yöntemiyle incelenmiş ve söz konusu kitaplarda matematik tarihinin ne derece kullanıldığı belirlenmeye çalışılmıştır. Bu inceleme ve verilerin analizi yapılırken Erdoğan, Eşmen ve Fındık'ın (2015) önerdiği sınıflandırmaya uygun olarak "tarihi notlar", "matematiğin kullanım alanlarına ilişkin notlar", "tarihsel notlarla birlikte uygulamaları" ve "öğrencinin okul dışı çalışmalarında yer alan tarihsel ögeler" kategorileri kullanılmıştır. Çalışma sonunda incelenen ders kitaplarında karşılaşılan 27 matematik tarihi ögesine çoğunlukla beşinci sınıf seviyesinde, konuya giriş aşamasında, sayılar ve işlemler öğrenme alanında, matematik dışındaki durumların tarihsel gelişimlerine ilişkin ufak tarihsel parçalar şeklinde yer verildiği görülmüştür. Bulgular ışı̆̆ında ortaokul matematik ders kitaplarında matematik tarihinden yeterince yararlanılmadığı söylenebilir.

Anahtar Kelimeler: Matematik ders kitapları, matematik tarihi, matematik eğitimi

Türkçe sürüm için tıklayınız

\section{Introduction}

The origin of mathematics that mankind uses to understand nature and to make its life sustainable within a certain framework and how it developed throughout history is undoubtedly important when considered in terms of the history of mathematics. While mathematics is a simple counting, measurement, and calculation work for some, it is a way of thinking, a technique of calculating by developing strategies (Agoshko \& Puel, 2009), and a communication tool in the context of being the common language of science (Yenilmez \& Uysal, 2007). Burton (2017) states that mathematics is "derived from the Greek word 'mathema,' which means knowledge, science and learning" used in the early inscriptions to indicate any teaching or field of study. Guillen (2010) defines mathematics as a field that has a single language for all humanity with regards to its structure and is of great importance in terms of being at the center of all technological developments and scientific achievements reached by humanity.

Russell (1872-1970), who put forward the logical basis of mathematics in Principia Mathematica, stated that mathematics associated with logic would help an individual understand mathematical knowledge. In addition, mathematics, which enables logical thinking in daily life and is accepted as a logical system (Baki, 2006; Baykul, 2003; Bruner, 1962; Charles, 2003; Hersh, 1997; Ministry of National Education [MoNE], 2018; National Council of Teachers of Mathematics [NCTM], 2000; Özmen 2004), has an important place in human life. It is a predictable fact that in the past, as in today, and tomorrow, humanity will have a fairly tight connection with mathematics. However, prejudices about mathematics in terms of mathematical concepts being related to each other, requiring problem-solving skills, representation of thought, not directly itself, but special 
symbols and signs expressing thought (Yıldırım, 1996) and relatively having an abstract language are directly related to how it is taught (Vygotsky, 1985; Hare, 1999). In this context, the history of mathematics is also included as one of the methods adopted in mathematics teaching in order for a student to think mathematically, to understand the value of mathematics, and to develop a positive attitude towards mathematics.

Nearly all of the research into the history of mathematics in a mathematics course (Albayrak, 2011; Baki \& Gürsoy, 2018; Başıbüyük, 2018; Canady, 1983; Ersoy, 2015; Göker, 1997; Gürsoy, 2010; Karakuş, 2009; Kaşıkç1, 2015; Lit, Siu \& Wong, 2001; Jankvist, 2009; Özcan, 2014; Özdemir \& Göktepe, 2012; Thomaidis \& Tzanakis, 2009; Tokay, 2019; Tözlüyurt, 2008; Varol, 2019; Yenilmez, 2011) concluded that there were positive increases in students' attitudes towards the course through their mathematical history practices in their mathematics course achievement, creativity (Ay, 2019), and interest and motivation for the course (Mersin, 2019). Besides, Küçükoğlu's (2019) suggested that students have a better understanding of the historical development and nature of mathematics in a teaching environment enriched with the history of mathematics. McBride and Rollins (1977) stated that, according to most of the students, mathematics is fixed, unchangeable, consists of a set of formulas and rules, while students can have more than one way to reach the results of mathematical problems, and that mathematics is a science that develops and enhances rather than just formulas after applied lessons in which mathematics history activities are used. Siu and Tzanakis (2004) argued that the history of mathematics should not be considered as a separate part of mathematics teaching but as an integrated and natural part. Just as it is not possible to consider art history separately from art, it is impossible to consider the history of mathematics separately from mathematics (Fauvel \& Van Maanen, 2002). Despite these positive defenses and results, studies on the use of the history of mathematics in mathematics teaching remain at the level of analysis and application on small groups.

Since the 1970s, studies mentioning the importance of the history of mathematics for mathematics education are observed in the literature. Today, the National Council of Teachers of Mathematics (NCTM), which primarily guides mathematics teaching worldwide, and the other institutions such as the International Study Group on the Relationship between the History and Pedagogy of Mathematics [HPM]) and the Mathematical Association of America are encouraging the use of the history of mathematics in mathematics teaching (Baş, 2019; Fried, 2001; Gençkaya, 2018). Hong Kong, which is mostly in the top ranks in international assessments, specifically touched on the use of mathematics history in the mathematics curriculum (Başıbüyük, 2018). In addition, there are supportive statements about including the history of mathematics in the curricula of countries such as China, Germany, Poland, and Portugal (Fauvel \& Maanen, 2002). Considering the new curriculums published in 2009, 2013, and 2018 (Illhan \& Aslaner, 2019) by the Ministry of National Education in Turkey, which included constructivist approaches in its curriculum as of 2005, in the 2009 mathematics curriculum, it was stated that it was among the general aims of contributing to students' understanding of how mathematics developed in the historical process, what role it played in the development of human thought, and how it provided benefits to other sciences. The curriculum does not only mention the importance of the history of mathematics but also includes examples of activities for the history of many concepts such as probability, rational numbers, clock, money, geometric objects, and measurement. (MoNE, 2009). In the 2013 mathematics curriculum, which was designed later, it was mentioned that the history of mathematics, which includes interesting anecdotes, important people, and their contributions to mathematics, would make mathematics lessons more meaningful for students. However, the history of mathematics was not mentioned at all in the 2018 secondary school mathematics curriculum. When the number of the studies conducted in recent years on the use of mathematics history in mathematics teaching and the positive results revealed by the scientific findings of these studies (Ay, 2019; Başıüyük, 2018; Bütüner, 2020; Furinghetti, 2019; Küçükoğlu, 2019; Mersin, 2019; Tokay, 2019; Varol, 2019), the secondary school mathematics curriculum does not include the history of mathematics. While this is the case regarding the curriculum, it may be necessary to examine the situation in the mathematics coursebooks, which is one of the main sources that can transfer the history of mathematics to students.

When studies examining the use of the history of mathematics in mathematics coursebooks (Baki \& Bütüner, 2013; Erdoğan, Eşmen \& Fındık, 2015; İncıkabı, Kepçeoğlu \& Küçükoğlu, 2017; Tan Şişman \& Kirez, 2018) are analyzed, it is seen that these studies are not conducted based on the coursebooks designed according to the last (2018) secondary school mathematics curriculum and that they are limited to presenting the current situation. In this study, unlike the previous studies, suggestions will be made regarding which examples of mathematics history can be used for which objective, at which class, and in which unit. In this context, this study seeks answers to the following questions regarding the elements of the history of mathematics and the use of the history of mathematics in the secondary school mathematics coursebooks distributed by the Ministry of National Education in Turkey to be taught in secondary schools affiliated to the Ministry of National Education in the 2019-2020 academic year:

$\checkmark$ How is the distribution of the course contents by grade levels?

$\checkmark$ How is the distribution by the stage of the course in the coursebooks? 
$\checkmark$ How is the distribution by usage methods?

$\checkmark$ How is the distribution by the learning domains?

$\checkmark \quad$ What can be the elements of the history of mathematics that can be suggested based on the grade levels according to the secondary school mathematics course curriculum?

\section{Method}

In this study, which examined the elements of the history of mathematics (EHM) included in the secondary school mathematics coursebooks organized according to the 2018 curriculum, a descriptive method of the qualitative research designs was used, and data suitable for the research questions were collected through document review. It is the analysis of written materials, which include data on the cases that are aimed to be researched, in terms of its scope and content (Yıldırım \& Şimşek, 2013). In this study, all rules underlined to be followed within the scope of "Higher Education Institutions Scientific Research and Publication Ethics Directive" were followed. Since the research is within the scope of document analysis, none of the actions stated under the title "Actions Against Scientific Research and Publication Ethics," which is the second part of the directive, were not taken.

\subsection{Data Collection Tool / Tools}

In the document review, mathematics coursebooks prepared by the Ministry of Education in Turkey to be taught in the 5th-8th grades of secondary school in accordance with the secondary school mathematics course curriculum adopted by the Board of Education in the 2019-2020 academic year were used. Details of the coursebooks included in the research are shown in Table 1.

Table 1. Coursebooks Reviewed in the Study

\begin{tabular}{|c|c|c|}
\hline Grade & Publisher & Half-title Explanation \\
\hline 5 th & SDR Dikey Publications & $\begin{array}{l}\text { This book has been accepted as a coursebook for } 5 \text { (five) years as of the } \\
2018-2019 \text { academic year with the decision of the Board of Education of } \\
\text { the Ministry of National Education dated } 28 / 05 / 2018 \text { and numbered } 78 \text { (in } \\
\text { the 170th row of the attached list). }\end{array}$ \\
\hline 6 th & Öğün Publications & $\begin{array}{l}\text { This book has been accepted as a coursebook for } 5 \text { (five) years as of the } \\
2019-2020 \text { academic year with the decision of the Board of Education of } \\
\text { the Ministry of National Education dated } 18 / 04 / 2019 \text { and numbered } 8 \text { (in } \\
\text { the } 173 \text { rd of the attached list). }\end{array}$ \\
\hline 7 th & EkoYay Publications & $\begin{array}{l}\text { This book has been accepted as a coursebook for } 5 \text { (five) years as of the } \\
2019-2020 \text { academic year with the decision of the Board of Education of } \\
\text { the Ministry of National Education dated 18/04/2019 and numbered } 8 \text { (in } \\
\text { the 163rd row of the attached list). }\end{array}$ \\
\hline 8th & Kök Publications & $\begin{array}{l}\text { This book has been accepted as a coursebook for } 5 \text { (five) years as of the } \\
\text { 2018-2019 academic year with the Board of Education of the Ministry of } \\
\text { National Education dated 28.05.2018 and numbered } 78 \text {. }\end{array}$ \\
\hline
\end{tabular}

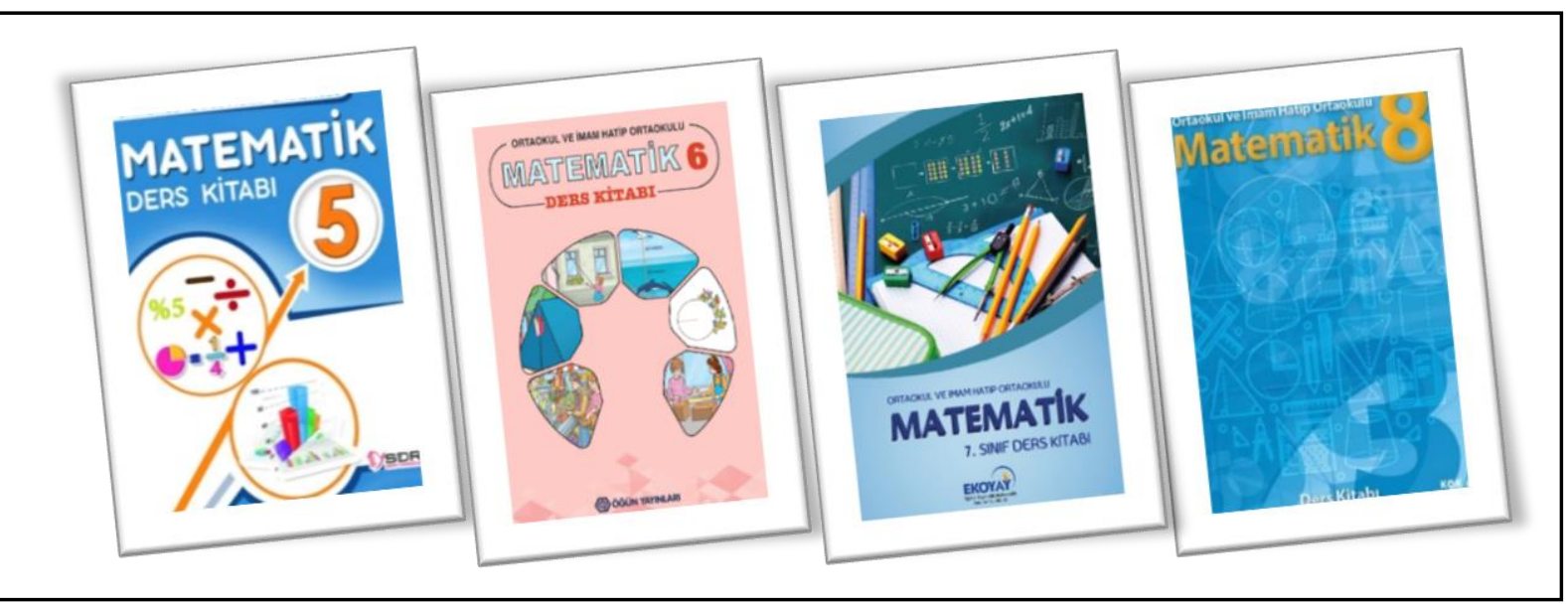

Figure 1. Coursebooks Reviewed in the Study 


\subsection{Data Analysis}

While examining the coursebooks included in the study, their distribution according to the elements of the history of mathematics (EHM) contents, grade levels, stage of the course, usage methods, and learning domains was discussed.

In data analysis, categories suitable for the classification suggested, especially by Erdoğan et al. (2015), were used. These categories were discussed in four parts to determine how the history of mathematics is used in the mathematics coursebooks and shown in Table 2. Next, the coursebooks were subjected to content analysis again according to the content classification of Mersin and Durmuş (2018) and Tzanakis and Arcavi (2000). In addition, the coding of the historical elements used in the coursebooks, the content, the usage methods, the stage of the course, the learning domain, and how this situation changed according to the grade levels with regards to the history of mathematics were carried out by three different experts. Findings were presented with percentages, frequency tables, graphs, and sample pictures.

Historical notes Notes giving information such as dates, biographies, anecdotes, the origin of symbols and words (How numbers were expressed in ancient civilizations, the historical development of pi, etc.).

Notes on usage Notes explaining the various uses of mathematics emerging in the historical process (using areas of mathematics primitive number symbols for counting, reading the order in nature with Fibonacci numbers, etc.).

Applications with historical notes

Explanation of notes on the history of mathematics with various examples or applications (showing how fractions are written, showing how to read number symbols, etc.).

Historical elements in students' extracurricular Items for extracurricular activities such as projects involving the history of mathematics and performance tasks (examination of a mathematician's studies, research on the history of a concept, etc.)

activities

Figure 2. Classification according to Erdoğan, Eşmen, and Fındık (2015)

Before starting to analyze the data, three experts made examinations to decide which item to be treated as EHM in which content and to reach a consensus. It was seen that Erdoğan et al. (2015) discussed the history of mathematics as "objects that clearly carry information about the fields of occupation of the history of mathematics" in their research. In this sense, some examples are given in Figures 3, 4, 5, and 6 to understand which element is suitable for which content.

\begin{tabular}{|c|c|c|c|c|c|c|c|c|c|c|}
\hline \multicolumn{11}{|l|}{$2,3,5,7,11,13,17,19,23,29, \ldots$} \\
\hline \multicolumn{11}{|c|}{$\begin{array}{l}\text { Examine the numbers given above. Make a comparison by remembering even and } \\
\text { odd natural numbers. Find the prime numbers up to } 100 \text { with the help of Sieve of } \\
\text { Eratosthenes and determine the common properties of these numbers. }\end{array}$} \\
\hline \multirow{10}{*}{$\begin{array}{l}\text { Since the number } 1 \text { has no divisor } \\
\text { other than itself in the hundred table on } \\
\text { the right, draw it over. } \\
\checkmark \text { Circle } 2 \text { and cross out its multiples. } \\
\checkmark \text { Circle } 3 \text { and cross out their multiples. } \\
\checkmark \text { Circle } 5 \text { and cross out its multiples. } \\
\checkmark \text { Circle } 7 \text { and cross out its multiples. } \\
\text { Circle the remaining numbers. Write } \\
\text { the numbers enclosed in the circle: } \\
2,3,5,7,11,13,17,19,23,29,31,37,41 \text {, } \\
43,49,53,59,61,67,71,73,79,83,89,97 \\
\text { The numbers we wrote above are } \\
\text { prime numbers up to } 100 \text {. Except for } 2 \text {, } \\
\text { the other prime numbers are the only } \\
\text { natural numbers. The prime numbers are } \\
1 \text {, and there is no divisor other than itself. }\end{array}$} & t & (2) & (3) & 4 & (5) & 6 & (7) & 8 & 9 & 10 \\
\hline & (11) & 12 & (13) & 14 & 15 & 16 & (17) & 18 & (19) & 20 \\
\hline & 21 & 22 & (23) & 24 & 25 & 26 & 27 & 28 & (29) & 30 \\
\hline & (31) & 32 & 33 & 34 & 35 & 36 & (37) & 38 & 39 & 40 \\
\hline & (41) & 42 & (43) & 44 & $45^{\circ}$ & 46 & (47) & 48 & 49 & 50 \\
\hline & 51 & 52 & (53) & 54 & 55 & 56 & 57 & 58 & (59) & 60 \\
\hline & (61) & 62 & 63 & 64 & 65 & 66 & (67) & 68 & 69 & 70 \\
\hline & (71) & 72 & (73) & 74 & 75 & 76 & nt & 78 & (79) & 80 \\
\hline & 81 & 82 & (83) & 84 & 85 & 86 & grt & 88 & (89) & 90 \\
\hline & 91 & 92 & 93 & 94 & 95 & 96 & (97) & 98 & 99 & 100 \\
\hline
\end{tabular}

Figure 3. An item that is not considered a historical item (Öğ̈̈n Publications. 6th grade, p. 48)

When the sieve of Eratosthenes activity in the 6th-grade mathematics coursebook is examined in Figure 2, it is seen that no historical data is included, and therefore such items were not considered as historical items. It could be regarded as a historical element if it was mentioned that Eratosthenes lived in the 250s BC and that the sieve in question was useful not only to find prime numbers from 1 to 100 but to any number of the desired size. 


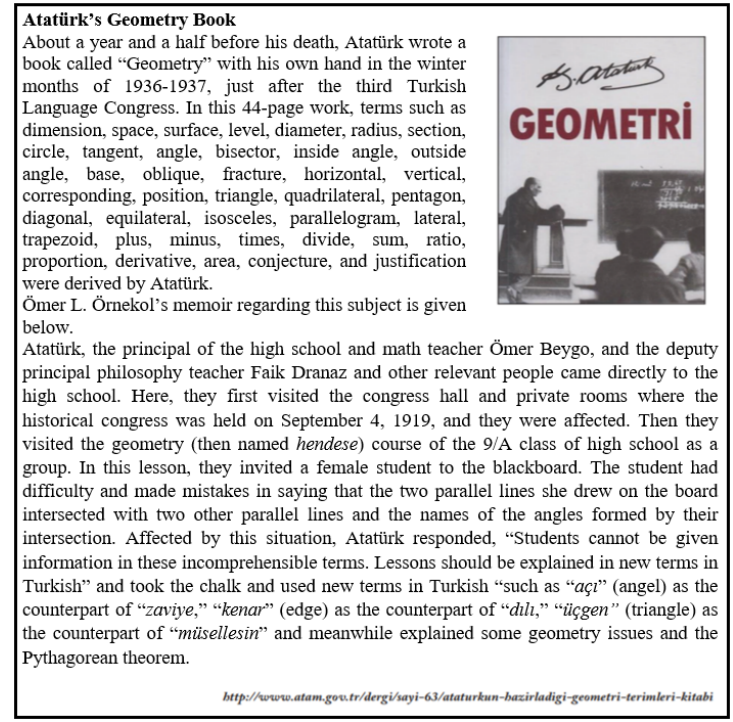

Figure 4. An item considered as a Historical Note (EkoYay Publications. 7th grade, p. 173)

As in Figure 3, the information provided only in the form of an information note or reading text was evaluated in the "historical note" category, without a direct connection to mathematics and without asking any questions or problems after the element.

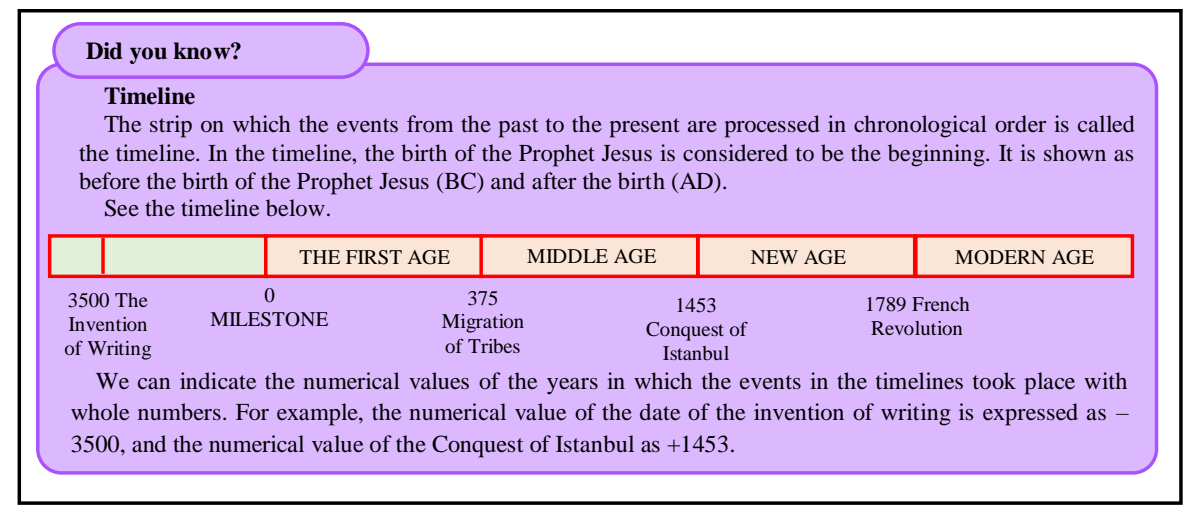

Figure 5. An item accepted as Notes on Usage Areas of Mathematics (Öğün Publications. 6th grade, p.85)

The notes and information in which other areas where mathematics is used are expressed as in Figure 4 are evaluated in the category of "notes on usage areas of mathematics." For example, another information note in the 7th-grade mathematics coursebook, in which the adoption date of the Turkish Flag measures and fixed rates are given, is also evaluated within this scope.

The first thing that comes to mind when it comes to the Dardanelles Campaign, the symbol of these battles, the Ottoman minelayer hero Nusret, dispersed the allied navy during the 18 March Naval War and became a source of joy for the Turkish nation. This ship laid 26 mines parallel to the shore, floating meters apart and 4.5 meters below the water. It has changed the fate of a war.

Accordingly, calculate how many meters the distance between the first mine and the last mine is.

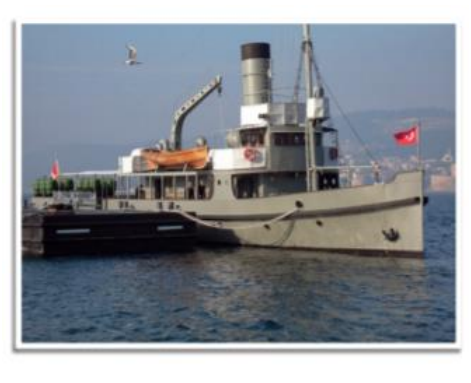

Figure 6. An item considered as Applications with Historical Notes (SDR Publications. 5th Grade, p. 235)

When Figure 5 is examined, information was given about the history of the Gallipoli War, and then a problem was asked in this context. Historical notes prepared in this way are included in the category of "applications with historical notes." 
Generally, in historical buildings, carpet and rug designs, ceramic and tile embroidery, a certain order and number of geometric shapes were used. It is possible to come across these geometric shapes in our historic and cultural works.

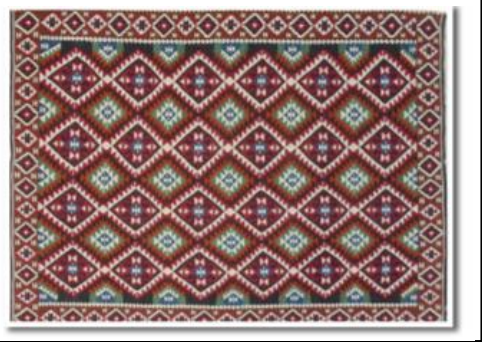

Figure 7. An example of historical elements in the students' extracurricular activities (SDR Publications. 5th Grade, p. 21)

The use of historical items in coursebooks in the form of information notes, pictures, and texts that students can come across in their extracurricular activities was evaluated in the category of "historical elements in extracurricular activities." Students can notice the patterns in daily life items such as carpets, rugs, ceramics, and tiles thanks to an information note as in Figure 7. Homework and project performance tasks related to the examination of the historical development of any mathematical concept or the contributions of a famous mathematician to mathematics were also included in this category. After the coursebook reviews, tables consisting of the history of mathematics items that can be recommended based on the grade levels according to the secondary school mathematics lesson curriculum were prepared with the support of experts. Suggestions for the Elements of the History of Mathematics (SEHM) are included in the research appendices.

\section{Findings}

In this section, tables and explanations including distribution of 27 EHMs (see Appendix 1) included in the coursebooks examined in this section according to their contents, usage areas, stage of the course in coursebooks, and learning domains are detailed.

Table 2. Distribution of the EHM contents of the items according to Erdoğan et al. (2015)

\begin{tabular}{lccccc}
\hline Categories & 5th Grade & 6th Grade & 7 th Grade & 8th Grade & Total \\
\hline Historical notes & 5 & 1 & 3 & 4 & 13 \\
Notes on usage areas of mathematics & 1 & 1 & 1 & 2 & 5 \\
$\begin{array}{l}\text { Applications with historical notes } \\
\text { Historical elements in students' extracurricular }\end{array}$ & 5 & 3 & - & - & 8 \\
activities & 1 & - & - & - & 1 \\
\hline Total & 12 & 5 & 4 & 6 & 27 \\
\hline
\end{tabular}

When Table 2, where the distribution of EHM contents in the coursebooks is given, is examined, it is seen that the grade level in which historical elements are used the most is the 5th grade $(n=12)$, and the category with the most historical elements is the historical notes $(n=13)$. It is noteworthy that the historical elements are almost never given in students' extracurricular activities $(\mathrm{n}=1)$, and the applications with historical notes are included only at the 5th $(n=5)$ and 6th $(n=3)$ grade levels. This situation can be interpreted as the emphasis on theory rather than practice as the students' age level increases. Besides, it can be stated that the notes on usage areas of mathematics are lower than expected $(n=5)$. The reason is that the curriculum, which emphasizes the relationship of mathematics with daily life, should include the elements of the history of mathematics related to daily life.

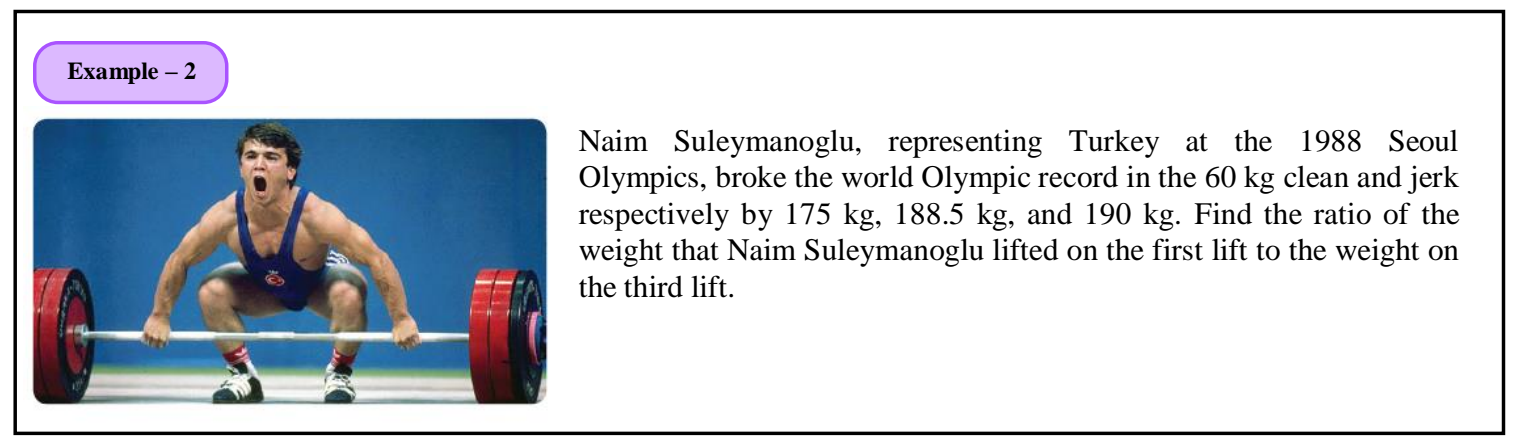

Figure 8. Applications with historical notes (6th Grade / Öğün Publications, p.174) 
Table 3. Distribution of EHM contents of items according to Mersin and Durmuş (2018)

\begin{tabular}{|c|c|c|c|c|c|}
\hline Contents & 5th Grade & 6th Grade & 7th Grade & 8th Grade & Total \\
\hline Life of Scientists & - & - & - & 1 & 1 \\
\hline Old Mathematical Methods & - & - & - & 1 & 1 \\
\hline $\begin{array}{l}\text { Historical Development of } \\
\text { Mathematical Concepts }\end{array}$ & 2 & 1 & 2 & 4 & 9 \\
\hline $\begin{array}{l}\text { Historical Development of a } \\
\text { Non-Mathematical Item }\end{array}$ & 10 & 4 & 2 & - & 16 \\
\hline Total & 12 & 5 & 4 & 6 & 27 \\
\hline
\end{tabular}

According to Table 3, which includes the contents of the EHM in the classification of Mersin and Durmuş (2018), it is seen that history is mostly used as the historical development of a non-mathematical element $(n=16)$. Information notes such as the discovery of the wheel, the invention of television, and the discovery of the thermometer are discussed under this category. In addition, elements such as the discovery of pi, the historical adventure of the tangram, the geometry book written by Atatürk, the emergence of square-rooted numbers are included in the historical development of mathematical concepts $(n=9)$. Besides, the introduction of Pythagoras, encountered in the 8th-grade coursebook, is categorized under the life of scientists $(n=1)$, and the information note in which the based 60 used by the Sumerians is described is included in the old mathematical methods $(n=1)$. In general, it can be suggested that the elements of the history of mathematics are not used in terms of content in the use of mathematics history in mathematics education.

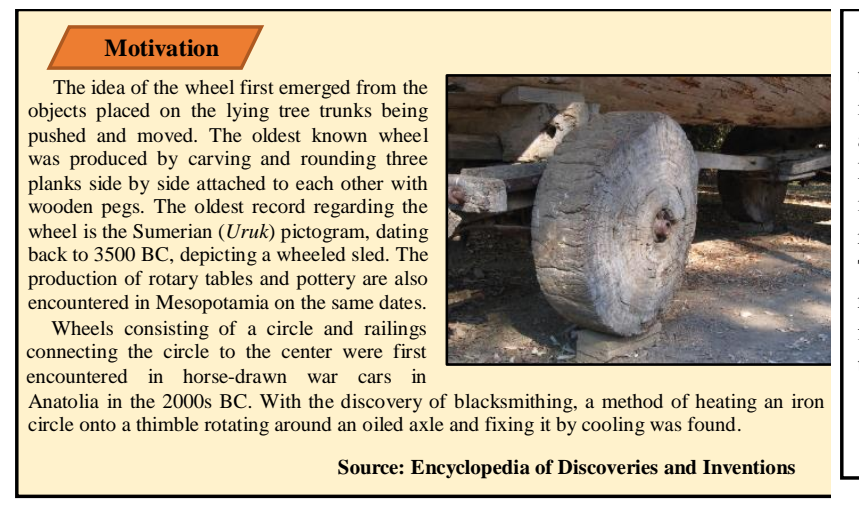

Figure 9. Historical Development of a Non-

Mathematical Item (7th Grade / EkoYay Publications, p.229)
Until proven otherwise, it was thought that all numbers are rational, that is, $\mathrm{m}$ and $\mathrm{n}$ ( $\mathrm{n}$ nonzero) $\mathrm{m}$ can be written as $\mathrm{m} / \mathrm{n}$, with $\mathrm{m}$ being integers. Pythagoras, who strongly defended this idea, tried to prove that all numbers are rational logically, but he did not succeed. The length of the two sides of an isosceles right triangle is 2 units. (You will learn to find the side lengths of right triangles in the following chapters).

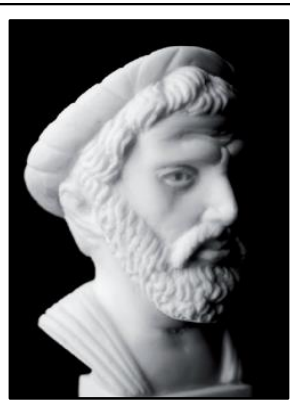

Pythagoras (Pythagoras, $569 \mathrm{BC}$ )
Figure 10. Historical Development of Mathematical Concepts (8th Grade / Kök Publications, p. 58)

Table 4. Distribution of EHM according to the ways of using by Tzanakis and Arcavi (2000)

\begin{tabular}{lccccc}
\hline Ways of Using & 5 th Grade & 6th Grade & 7 th Grade & 8 th Grade & Total \\
\hline Historical snippets & 11 & 3 & 4 & 4 & 22 \\
Experiential mathematical activities & 1 & 1 & - & - & 2 \\
The World Wide Web & - & 1 & - & - & 1 \\
Worksheets & - & - & - & - & - \\
Historical packages & - & - & - & - & - \\
Historical problems & - & - & - & - & 1 \\
Mechanical instrument & - & - & - & - & - \\
Research projects based on history & - & - & - & - & - \\
texts & - & - & - & - \\
Plays & - & - & - & - & - \\
Films and other visual means & - & - & - & - & 1 \\
Outdoors experience & - & - & - & - \\
Primary sources & - & - & - & 6 \\
Taking advantage of errors of & 12 & 5 & 4 & \\
mathematicians & & & & 27 \\
\hline Total & & & & - \\
\hline
\end{tabular}

As can be seen in Table 4, out of 27 EHMs identified in secondary school mathematics coursebooks, 22 were historical snippets, 2 were experimental mathematical activities, 1 was a world wide web search that led the student to research, 1 was a mechanical instrument, and 1 was a primary source. Historical problems, research projects based on historical texts, plays, films, and other visual means, outdoor experience, primary sources, and 
taking advantage of errors of mathematicians were never mentioned. From this point of view, it can be underlined that the number of EHMs used in the coursebooks is low, and the variety is not sufficient.

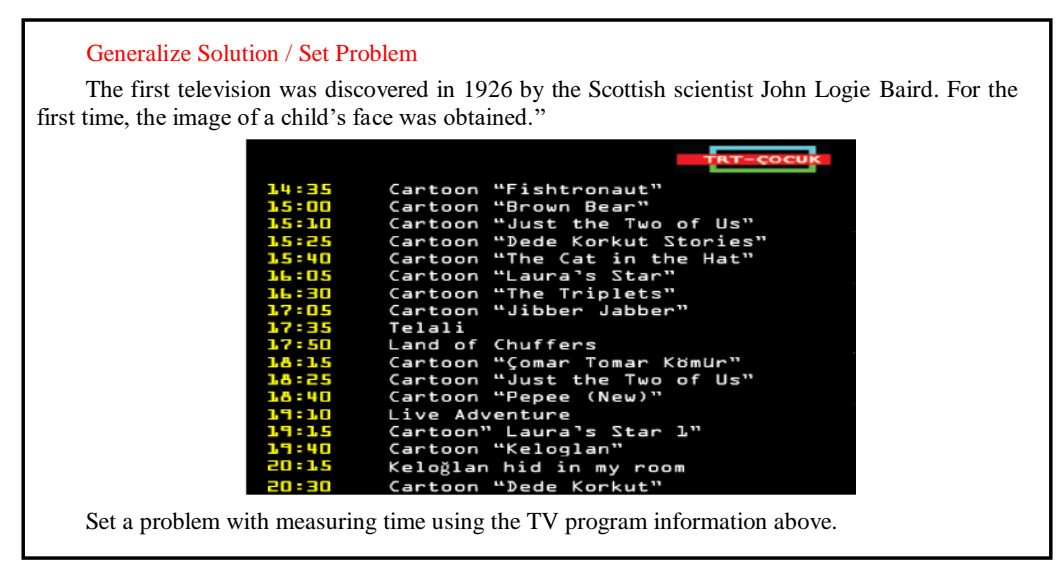

Figure 11. A Historical Snippet (5th Grade / SDR Yayıncılık, p.249)

Table 5. EHM distribution by the stage of the course

\begin{tabular}{lccccc}
\hline Stage of the Course & 5th Grade & 6th Grade & 7th Grade & 8th Grade & Total \\
\hline Pre-teaching & 6 & 2 & 2 & 5 & 15 \\
While-teaching & 3 & 1 & 1 & 1 & 6 \\
Post-teaching & 3 & 2 & 1 & - & 6 \\
\hline Total & 12 & 5 & 4 & 6 & 27 \\
\hline
\end{tabular}

\begin{abstract}
With the declaration of the 1st Constitutional Era on December 23, 1876, the Ottoman Empire moves into the parliamentary system. The first elections in the history of Turkey were held in 1876, 142 years before today when the Ottoman Empire entered the parliamentary system. As a result of this election, which was held for 130 members of the First Parliament, the first assembly was opened with a ceremony in the Great Hall in the Dolmabahce Palace with a total of 115 deputies, 69 Muslims and 46 non-Muslims.
\end{abstract}

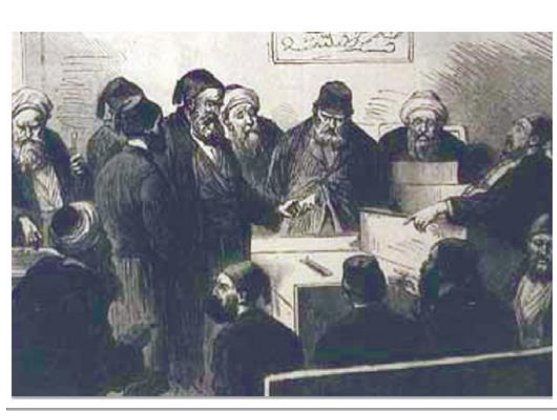

Figure 12. An item used in the pre-teaching stage of the Subject (5th Grade / SDR Publications, p.216)

When Table 5, which includes EHM distributions according to the stage of the course, is examined, it is seen that 15 of the 27 historical items encountered in the books are used in the pre-teaching of the subject, 6 are used in the while-teaching of the subject, and 6 are used at the post-teaching and evaluation of the subject. Based on this, it can be said that the history of mathematics is mostly used to motivate students and draw their attention to the lesson.

Table 6. EHM distribution by learning domains

\begin{tabular}{lccccc}
\hline Learning Domains & 5th Grade & 6th Grade & 7th Grade & 8th Grade & Total \\
\hline Numbers and Operations & 4 & 4 & 1 & 3 & 12 \\
Algebra & - & - & - & - & - \\
Geometry and & 2 & 1 & 3 & 1 & 7 \\
Measurement & 6 & - & - & - & 6 \\
Data Processing & - & - & - & 2 & 2 \\
Probability & 12 & 5 & 4 & 6 & 27 \\
\hline Total & & &
\end{tabular}

According to the new secondary school mathematics curriculum, Geometry and Measurement, Numbers and Operations, and Data Processing learning domains are included at all grades, while the Algebra learning domain is taught as of the 6th grade, and the probability learning domain is only included in the 8th grade. In this context, the history of mathematics items related to the probability learning domain were seen only in the 8th grade $(n=2)$ mathematics coursebook. Besides, EHMs were not included in any learning level related to the field 
of learning algebra. There are 4 items at the 5th-grade level, 4 at the 6 th-grade level, 1 at the 7 th-grade level, and 3 in the 8th-grade related to the learning domain of numbers and operations. In this sense, the learning domain where the history of mathematics is mostly used is numbers and operations $(n=12)$. It is also significant that in the field of data processing learning, EHM was included only in the 5 th grade $(n=6)$. Besides, there are 2 items at the 5th-grade level, 1 item at the 6th-grade level, 3 items at the 7th-grade level, and 1 item at the 8th-grade level related to the geometry learning domain. Another learning domain where the history of mathematics is used extensively is the geometry $(n=7)$ learning domain.

In the past, a rich man named Tan lived in China. He had a beautiful plate. Hearing that the king will come to town one day, Tan wanted to present this valuable plate to the king. The plate that fell on the floor while polishing it was divided into seven pieces. Tan tried to create squareshaped porcelain by bringing the pieces together. He realized that while doing this process, he could obtain more than 7000 different shapes. The tangram puzzle consisting of five triangles, a square, and a parallelogram was thus created.

Name the polygonal regions that make up the tangram.

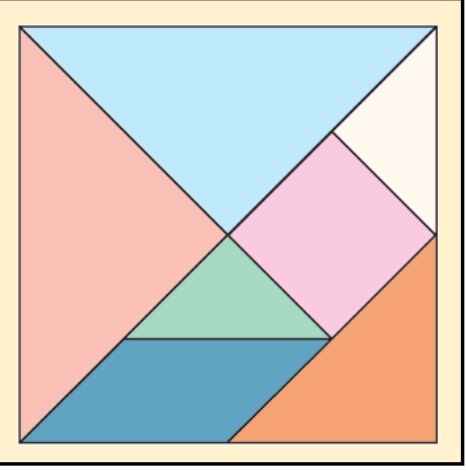

Figure 13. Geometry and Measurement (7th Grade / EkoYay Publications, p.188)

\section{Discussion and Conclusion}

In this study, which investigates the extent to which the history of mathematics is used in secondary school mathematics coursebooks, the content, usage methods, stage of the course, learning domain, and how all these topics change based on the elements of the history of mathematics and according to grade levels of 4 secondary school mathematics coursebooks used in the 2018-2019 academic year were reviewed. As a result of the document review, 27 EHMs were determined. This number means 6.5 EHMs per coursebook. While Baki and Bütüner (2013) found 19 EHMs in 3 coursebooks in their study in which they examined the 6th, $7^{\text {th }}$, and 8thgrade coursebooks in terms of mathematics history, Erdoğan, Eşmen and Findık (2015) examined 7 secondary school coursebooks that were taught in 2013-2014 and determined 27 EHMs. Besides, İncikab1 et al. (2019) examined 8 mathematics coursebooks used in 2016-2017 and reached 15 EHMs. Additionally, Mersin and Durmuş (2018) stated that they found out 19 items from 4 coursebooks in their study in which they examined the coursebooks used in the same years. Tan Şişman and Kirez (2018) suggested that 27 historical elements were included in 6 mathematics coursebooks used in 2015-2016. Compared to the studies conducted, although no historical context was discussed in the 2018 secondary school mathematics curriculum, the number of EHMs used has increased every year. Although this is the case quantitatively, it can be said that the historical elements used are insufficient in terms of their relationship with mathematics.

As a result of the classification of the scope of the EHM in the analyzed coursebooks according to Erdogan et al. (2015), it is seen that the grade level where historical elements are used most is the fifth grade, and the category with the most is historical notes. The fact that historical notes are historical information that is not related to mathematics can be said to be incompatible with the context of the contribution of the history of mathematics to mathematics education. It is significant to note that the historical elements in the students' extracurricular activities are almost never given $(n=1)$, while applications with historical notes are seen only at the fifth and sixth-grade level. This case can be interpreted as the emphasis on theory rather than practice as the age level of the students grows. In addition, it was observed that the section devoted to notes on usage area of mathematics was not sufficient. These findings are in line with the other studies (Baki \& Bütüner, 2013; Erdoğan et al., 2015; İncıkabı et al., 2017; Tan Şişman \& Kirez, 2018) in the context of using the history of mathematics. Although the importance of the relationship of mathematics with everyday life is often emphasized (MoNE, 2018), it is noteworthy that coursebooks prepared in accordance with the constructivist approach do not include historical notes on the use of mathematics in extracurricular activities and daily life. Ancient civilizations used various number systems to meet their daily needs. They used bones to indicate quantities and measurements, and they made calculations on them using notches of waste and sometimes pieces of stone and wood (Krantz, 2006). When studies on the history of mathematics (Struik, 2011; Cajori, 2014; Burton, 2017) are examined, it can be seen how many daily needs contribute to the growth and development of mathematics in the process. It can be said that the EHM, which indicates how the Babylonian, Egyptian, Maya Civilizations, Chinese, Indian, Greek, and Islamic societies use mathematics in accordance with the student level, will attract the attention of the students and contribute positively to the motivation of the lesson (Başıüyük, 2018), so it should be included in the coursebooks. 
In the content classification of mathematical history elements made according to Tzanakis and Arcavi (2000), it was seen that most of the elements encountered were in the form of the historical development of a nonmathematical item. It can be suggested said that there are some elements, although not sufficient, in the category of the historical development of mathematical concepts. Moreover, historical items related to the life of scientists and ancient mathematical methods were included in the eighth-grade coursebook only once. Considering the contents and frequencies of the aforementioned items in general, it can be said that the EHM is not used in a manner that covers the purposes of using the history of mathematics in mathematics education. The inclusion of historical notes, mathematicians' contributions to science, or their lives in textbooks does not bring the history of mathematics to be used in mathematics lessons (Swetz, 1997; Fried, 2001). All of these elements should be given with mathematical associations and designed as a part of the teaching by establishing a connection with the subject being taught. For example, the statement that the golden ratio is based on the sequence of numbers put forward by the Italian mathematician Leonardo Fibonacci, who lived in the 1170s, inspired by a simple rabbit problem, would undoubtedly cause a considerable interest in a learning environment where the rabbit problem was solved. In this context, it should be ensured that the history of mathematics is made effective by reconstructing its function both in coursebooks and within the scope of mathematics courses.

When the EHMs used in coursebooks were classified according to the usage methods, it was seen that most of the items were historical snippets, 2 were experimental mathematical activities, 1 was a world wide web search that led the student to research, 1 was a mechanical instrument, and 1 is a primary source. Historical problems, research projects based on historical texts, plays, films, and other visual means, outdoor experience, primary sources, and taking advantage of errors of mathematicians were never mentioned. From this point of view, it can be expressed that the number of EHMs used in the coursebooks is low, and the variety is not sufficient. In their study on the history of mathematics, Clark (2012) stated that including mathematical history activities in teaching developed different mathematical perspectives in students. It is an undeniable fact that helping students reveal different perspectives also supports their cognitive development (Cheung, 2014). In this respect, parallel to other studies in the literature, it can be argued that the EHMs reviewed has little contribution to students' cognitive development.

When the EHMs were examined according to the stage of the course, it was observed that they were included in the while-teaching and post-teaching of the subject, generally in the pre-teaching of the subject. In this case, it can be thought that EHMs are given more place in the pre-teaching phase of the subject in order to grab the attention of the students in the introduction of the lesson and to motivate them about the lesson. It can be stated that these findings are in line with other studies on this topic (Baki \& Bütüner, 2013; Erdoğan, Eşmen, \& Fındık, 2015). In fact, there are many studies (Ersoy, 2015; Kaşıkç1, 2015; Mersin, 2019; Ay, 2019) asserting that historical elements have positive effects on students' attitudes towards mathematics course and their motivation towards the course. In the classification made according to learning domains, 12 items for numbers and operations, 8 for geometry and measurement, 6 for data processing, and 2 for probability were reviewed in terms of the elements of the history of mathematics, while no note from the history of mathematics was included in any of the four books on algebra. It is interesting that al-Khwarizmi (d. 303), who is regarded as the father of Algebra (Fazlıoglu, 1997), or the source of the " $\mathrm{x}$ " sign were never mentioned to the students.

\section{Suggestions}

In the light of the study results, it can be asserted that although the importance of its use in mathematics education has been emphasized in many studies, the history of mathematics is not sufficiently and effectively in the educational environments. This study is a research that quantitatively examines only the historical elements included in secondary school coursebooks. In future studies, coursebooks at different learning levels can be examined in the context of the history of mathematics by including excerpts from the coursebooks.

It was underlined in the literature that historical notes related to non-mathematical or mathematical science, the contributions of mathematicians to science, or the inclusion of their lives in coursebooks alone is not enough for the effectiveness of the history of mathematics. The history of mathematics can be used in mathematics teaching or in mathematics coursebooks, and also can be designed as a part of the subject by various associations, not in a way that is disconnected from each other or from the subject to be learned.

Exploring or conveying the historical developments of mathematical concepts, how and with what needs they emerged, will undoubtedly help them learn the concepts in question. Coursebooks can be enriched in terms of using activities such as games, museum trips, regional discoveries, drama, and group projects, rather than just providing information to learn these concepts.

One of the main sources that will enable students to access mathematics and mathematical concepts is teachers besides the coursebooks. Teachers should be equipped with which EHM to use in which stage of the course. In this context, the inclusion of the history of mathematics course by the institutions that train teachers 
can be prepared in these courses in which historical elements are taught by associating them with the curriculum. Teachers can also be supported by practical in-service training during which they design activities.

It is stated in the literature that activities related to the history of mathematics should be included in mathematics courses. However, since the history of mathematics was not mentioned in any way in the secondary school mathematics curriculum updated in 2018, it seems impossible to include such activities with the thought that they will disrupt the mathematics curriculum. As designed in the 2009 mathematics curriculum, objectives in this field can be included in the latest curriculum too.

There are many topics in the history of mathematics that can be brought into the learning environment in accordance with the levels of students. Some suggestions can be made as a result of the review carried out within the scope of this study to be included in the coursebooks on a grade basis:

$\checkmark$ Suggestions for the 5th Grade Mathematics Coursebook

The historical elements such as Ancient Egyptian mathematics, the history of numbers, the first representations of fractions, operations with fractions in the Ottoman Madrasahs, Jamshīd al-Kāshī, Atatürk's geometry book, the inventor of graphics: William Playfair, the invention of the clock and its historical development, and Atatürk's standardization of units of measure, can be included.

\section{$\checkmark$ Suggestions for the 6th Grade Mathematics Coursebook}

The historical elements such as Roman numbers, the sieve of Eratosthenes, George Cantor and the concept of sets, timeline, decimal numbers explorer: Jamshīd al-Kāshī, golden ratio and Fibonacci, the concept of the unknown in the Ottoman Empire, the inventor of graphics: William Playfair, Atatürk's geometry book, Atatürk's standardization of units of measure, the discovery of the pi can be used in coursebooks.

\section{$\checkmark$ Suggestions for the 7th Grade Mathematics Coursebook}

The historical elements such as Galileo Thermometer, the concept of infinity, fractions in Ottoman Madrasas, Gauss's theorem, The Lord of Equations: Omar Khayyam, Atatürk's geometry book, how bees make the honeycombs in the form of a hexagon, the discovery of the pi, the inventor of graphics: William Playfair can be used to teach the mathematical concepts in coursebooks.

\section{$\checkmark$ Suggestions for the 8th Grade Mathematics Coursebook}

The historical elements such as the sieve of Eratosthenes, the relationship between chess and exponential numbers, the story of the root number 2, Pascal and probability, Muhammad ibn Mūsā al-Khwārizmī and Algebra, History of Analytic Geometry, Atatürk's geometry book, Thales Theorem, Painter Echer, and Egyptian Pyramids can be included in secondary school mathematics coursebooks.

\section{Appendices}

Appendix 1. Elements of the History of Mathematics (EHMs) obtained in the reviewed coursebooks

\begin{tabular}{|c|c|c|c|c|c|}
\hline & Grade & Unit & Page & Subject & Content \\
\hline EHM 1 & 5 & Unit 1 & 63 & $\begin{array}{l}\text { Exponential } \\
\text { Expressions }\end{array}$ & $\begin{array}{l}\text { Bacteria were used for the first time in the } 17 \text { th } \\
\text { century. }\end{array}$ \\
\hline EHM 2 & 5 & Unit 1 & 21 & $\begin{array}{l}\text { Number and Shape } \\
\text { Patterns }\end{array}$ & Patterns and Lines in Historical Buildings \\
\hline EHM 3 & 5 & Unit 2 & 87. & $\begin{array}{l}\text { Integer and Compound } \\
\text { Fractions }\end{array}$ & Currencies and Historical Money pictures \\
\hline EHM 4 & 5 & Unit 3 & 130. & $\begin{array}{l}\text { Decimal } \\
\text { Representations }\end{array}$ & World Records in Athletics \\
\hline EHM 5 & 5 & Unit 4 & 199. & $\begin{array}{l}\text { Triangles and } \\
\text { Quadrilaterals }\end{array}$ & $\begin{array}{l}\text { The Turkish Origin of the Word Baklava and the } \\
\text { Place of Baklava in History }\end{array}$ \\
\hline MTÖ 6 & 5 & Unit 5 & 216 & Data Processing & $\begin{array}{l}\text { Distribution of the Members of the Parliament in } \\
\text { the Ottoman State }\end{array}$ \\
\hline EHM 7 & 5 & Unit 5 & 225 & Data Interpretation & $\begin{array}{l}\text { Establishment of the State Institute of Statistics in } \\
1926\end{array}$ \\
\hline EHM 8 & 5 & Unit 5 & 235 & Data Collecting & A Question on the Gallipoli War \\
\hline EHM 9 & 5 & Unit 5 & 247 & Data Collecting & An Example of July 15th and Ömer Halis Demir \\
\hline EHM 10 & 5 & Unit 5 & 248 & Data Collecting & Recognition of Turkish Women for Election \\
\hline EHM 11 & 5 & Unit 5 & 249 & Data Collecting & The Invention of Television \\
\hline EHM 12 & 5 & Unit 6 & 259 & Measuring Area & The Invention of Plasma Technology \\
\hline EHM 13 & 6 & Unit 1 & 18 & Exponential Numbers & Facts about Chess \\
\hline EHM 14 & 6 & Unit 1 & 29 & Problem Solving & $\begin{array}{l}\text { Continuous Development of Mathematics Since } \\
\text { History }\end{array}$ \\
\hline
\end{tabular}




\begin{tabular}{|c|c|c|c|c|c|}
\hline \multicolumn{6}{|c|}{ Appendix 1 contmued } \\
\hline EHM 15 & 6 & Unit 2 & 85 & Absolute Value & Explaining the Absolute Position using a Timeline \\
\hline EHM 16 & 6 & Unit 3 & 174 & Ratio & Record broken by Naim Süleymanoğlu \\
\hline EHM 17 & 6 & Unit 6 & 306 & Circles & How Pi was Found \\
\hline EHM 18 & 7 & Unit 4 & 160 & Ratios & $\begin{array}{l}\text { The Proportions of the Length and Width of the } \\
\text { Turkish Flag and the Decision of These Ratios }\end{array}$ \\
\hline EHM 19 & 7 & Unit 5 & 173 & Lines and Angles & Atatürk’s Geometry Book \\
\hline EHM 20 & 7 & Unit 5 & 229 & Circles & The Invention of the Wheel \\
\hline EHM 21 & 7 & Unit 5 & 188 & Polygons & The Story of Tangram \\
\hline EHM 22 & 8 & Unit 1 & 11 & $\begin{array}{l}\text { Multipliers and } \\
\text { Multiples }\end{array}$ & $\begin{array}{l}\text { The Invention of the First Calculator by Pascal in } \\
1645\end{array}$ \\
\hline EHM 23 & 8 & Unit 1 & 12 & $\begin{array}{l}\text { Multipliers and } \\
\text { Multiples }\end{array}$ & $\begin{array}{l}\text { The Sumerians' Use of the Base } 60 \text { System in } \\
\text { Mathematics }\end{array}$ \\
\hline EHM 24 & 8 & Unit 2 & 58 & $\begin{array}{l}\text { Square Root } \\
\text { Expressions }\end{array}$ & How Pythagoras Defines Square Root of 2 \\
\hline EHM 25 & 8 & Unit 3 & 103 & $\begin{array}{l}\text { Probability and } \\
\text { Algebra }\end{array}$ & The Birth of the Concept of Probability \\
\hline EHM 26 & 8 & Unit 6 & 263 & $\begin{array}{l}\text { Geometry and } \\
\text { Measurement }\end{array}$ & $\begin{array}{l}\text { The Structure and History of Arundel Castle in } \\
\text { England }\end{array}$ \\
\hline EHM 27 & 8 & Unit 6 & 278 & Geometric Objects & Turks' Use of Drums \\
\hline
\end{tabular}

Appendix 2: Suggestions for the Elements of the History of Mathematics (SEHM) based on the Secondary School Mathematics Course Curriculum in accordance with the 5th Grade Level

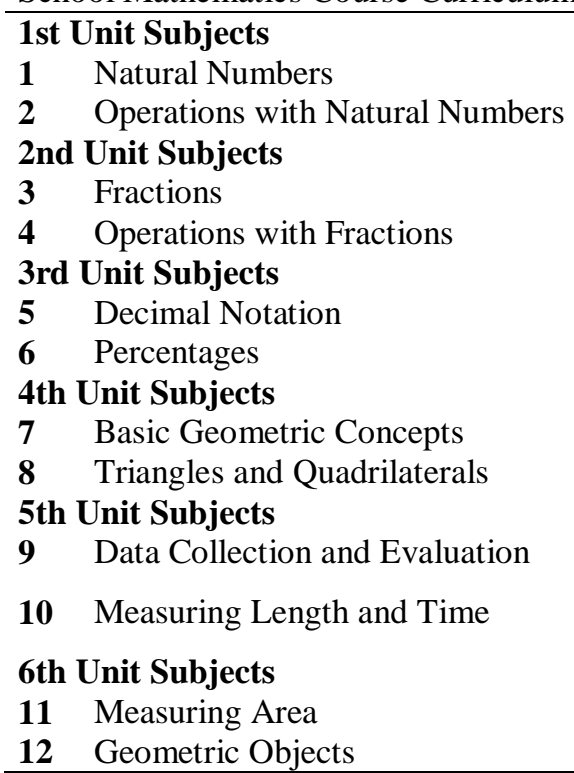

SEHM5.1 - Ancient Egyptian Mathematics

SEHM5.2 - Natural Numbers and a Brief History of Operations

SEHM5.3 - Historical Notes on the Representation of Fractions SEHM5.4 - Operations with Fractions in Ottoman Madrasas

SEHM5.5 - Jamshīd al-Kāshī and Mathematics

SEHM5.6 - The First Use of the Percent Sign

SEHM5.7 - Atatürk's Geometry book

SEHM5.7 - Atatürk's Geometry book

SEHM5.8 - The Inventor of Graphics: William Playfair SEHM5.9 - The Invention and Historical Development of the Clock

SEHM5.10 - Atatürk's Standardization of Units of Measure SEHM5.11 - Weld-Blundell Prism

Appendix 3. Suggestions for the Elements of the History of Mathematics (SEHM) based on the Secondary School Mathematics Course Curriculum in accordance with the 6th Grade Level

\section{1st Unit Subjects}

1 Operations with Natural Numbers

2 Multipliers and Multiples

3 Sets

2nd Unit Subjects

4 Integers

5 Operations with Fractions

3rd Unit Subjects

6 Decimal Notation

7 Ratio

4th Unit Subjects

8 Algebraic Expressions

9 Data Collection and Evaluation

10 Data Analysis
SEHM6.1 - Roman Numerals

SEHM6.2 - The Sieve of Eratosthenes

SEHM6.3 - Georg Cantor's Intuitive Set Concept

SEHM6.4 - The Concept of Milestone and the Timeline

SEHM6.5 - Operations with Fractions in Ottoman Madrasas

SEHM6.6 - Explorer of the Decimal Numbers: Jamshīd al-Kāshī SEHM6.7 - The Golden Ratio and Fibonacci

SEHM6.8 - "X" in Ottoman

SEHM6.9 - The Inventor of Graphics: William Playfair

SEHM6.9 - The Inventor of Graphics: William Playfair 
Appendix 3 continued

\begin{tabular}{l|l|}
\hline 5th & Unit Subjects \\
\hline 11 & Angles \\
12 & Measuring Area \\
6th & Unit Subjects \\
$\mathbf{1 3}$ & Circle \\
\hline 14 & Geometric Objects \\
\hline
\end{tabular}

SEHM6.10 - Atatürk's Geometry book

SEHM6.11 - Atatürk's Standardization of Units of Measure

SEHM6.12 - Discovery of Pi

SEHM6.13 - Weld-Blundell prism

Table Appendix 4. Suggestions for the Elements of the History of Mathematics (SEHM) based on the Secondary School Mathematics Course Curriculum in accordance with the 7th Grade Level

\section{1st Unit Subjects \\ 1 Operations with Integers \\ 2nd Unit Subjects}

2 Rational numbers

3 Operations with Rational Numbers

3rd Unit Subjects

4 Algebraic Expressions

5 Equality And Equation

4th Unit Subjects

6 Ratio and Proportion

7 Percentages

5th Unit Subjects

8 Lines and Angles

9 Polygons

10 Circles

6th Unit Subjects

11 Data Analysis

12 Views of Objects from Different Directions
SEHM7.1 - A problem about the Galileo Thermometer

SEHM7.2 - Why can't the denominator be "0"? Concept Of Infinity

SEHM7.3 - Operations with Fractions in Ottoman Madrasas

SEHM7.4 - Little Gauss's Story and Theorem

SEHM7.5 - The Lord of Equations: Omar Khayyam

SEHM7.6 - The Golden Ratio and Fibonacci

SEHM7.7 - The First Use of the Percent Sign

SEHM7.8 - Atatürk's Geometry book

SEHM7.9 - Bees Know Mathematics

SEHM7.10 - Discovery of Pi

SEHM7.11 - The Inventor of Graphics: William Playfair

SEHM7.12 - Atatürk's Standardization of Units of Measure

Table Appendix 5. Suggestions for the Elements of the History of Mathematics (SEHM) based on the Secondary School Mathematics Course Curriculum in accordance with the 8th Grade Level

\section{1st Unit Subjects}

1 Multipliers and Multiples

2 Exponential Expressions

2nd Unit Subjects

3 Square Root Expressions

4 Data Analysis

3rd Unit Subjects

5 Basic Topics of Probability

6 Algebraic Expressions and Identities

4th Unit Subjects

7 Linear Equations

8 Inequalities

5th Unit Subjects

9 Triangles

10 Congruence and Similarity

6th Unit Subjects

11 Transformation Geometry

12 Geometric Objects
SEHM8.1 - The Sieve of Eratosthenes

SEHM8.2 - Chess and the King's Promise

SEHM8.3 - The story of the number $\sqrt{2}$

SEHM8.4 - The Inventor of Graphics: William Playfair

SEHM8.5 - Fair Dice: Pascal

SEHM8.6 - The Eponym of Algebra: al-Khwarizmi

SEHM8.7 - Homework work on the History of Analytic Geometry SEHM8.8 -

SEHM8.9 - Atatürk's Geometry book

SEHM8.10 - Thales Theorem

SEHM8.11 - The Man Who Portrays Mathematics: Escher SEHM8.12 - Mysterious Architecture: Egyptian Pyramids 


\section{Ortaokul Matematik Ders Kitaplarında Matematik Tarihine Yönelik İçeriklerin İncelenmesi}

\section{Giriş}

İnsanoğlunun doğayı anlama ve yaşamını belirli bir çerçevede sürdürülebilir hale getirmek için kullandığ1 matematiğin kökeni ve tarih boyunca nasıl geliştiği, söz konusu matematiğin tarihi olunca şüphesiz ki önemlidir. Matematik bazıları için basit bir sayma, ölçme ve hesap işi iken, bazıları için ise, bir düşünme biçimi, strateji geliştirerek hesaplama tekniği (Agoshko ve Puel, 2009), bilimin ortak dili olması bağlamında bir iletiş̧im aracıdır (Yenilmez ve Uysal, 2007). Burton (2017) matematiğin, "ilk yazıtlarda herhangi bir öğretim ya da çalışma alanını göstermek için kullanılan "bilgi, bilim ve öğrenme" anlamlarındaki Yunanca "mathema" kelimesinden türetildiğini" ifade eder. Guillen (2010), matematiği, yapısı bağlamında tüm insanlık için tek bir dile sahip olan, insanlığın eriştiği bütün teknolojik gelişmelerin ve bilimsel başarıların kaynağında yer alması açısından büyük önem taşıyan bir alan olarak tanımlar.

Matematiğin mantıksal temelini Principia Mathematica'da ortaya koyan Russell (1872-1970) mantıkla ilişkilendirilen matematiğin bireyin matematiksel bilgiyi kavramasına yardımcı olacağını belirtmiş̧ir. Ayrıca günlük yaşamda mantıklı düşünmeyi sağlayan, mantıklı bir sistem olarak kabul edilen matematik (Baki, 2006; Baykul, 2003; Bruner, 1962; Charles, 2003; Hersh, 1997; Milli Eğitim Bakanlığı [MEB], 2018; National Council of Teachers of Mathematics [NCTM], 2000; Özmen 2004) insan yaşamında önemli bir yere sahiptir. Geçmişte, bugünde olduğu gibi ve yarında da insanoğlunun matematikle oldukça sıkı bir bağının olacağı öngörülebilir bir gerçektir. Ancak matematik, içerisindeki matematiksel kavramların birbiriyle ilişkili olması, problem çözme becerisi gerektirmesi, düşüncenin doğrudan kendisini değil, düşünceyi ifade eden özel sembol ve simgeleri temsil etmesi (Yıldırım, 1996), buna bağlı olarak soyut bir dile sahip olması bakımından matematik hakkındaki önyargılar, onun nasıl öğretildiği ile doğrudan alakalıdır (Hare, 1999; Vygotsky, 1985). Bu bağlamda matematik öğretiminde, öğrencinin matematiksel düşünebilmesi, matematiğin değerini kavrayabilmesi matematiğe karş1 pozitif bir tutum geliş̧irmesi için benimsenen yöntemlerden biri olarak matematik tarihine de yer verilmiştir.

Matematik tarihi, matematiğin asırlar geçtikçe ne şekilde geliştiğini ve farklı medeniyetlerce hangi şekillerde ele alındığını gösteren bir alandır (Baki, 2014). Fried (2001), matematiği daha anlaşılabilir, enteresan ve yaklaşılabilir hale getirmesi, bir insan etkinliği ve ürünü olarak algılanmasına yardımcı olması ve matematiksel kavram ve problemlerin iç yüzünün fark edilmesi bağlamında matematik tarihinin matematik derslerinde kullanılması gerektiğini söylemiştir. Gulikers ve Blom (2001) da öğrencilerin güdülenmelerini temele alarak, matematik tarihine ait problemlerle uğraşmalarının ve bu problemlere güncel çözüm yolları bulmalarının onları derse motive edeceğini, matematik korkularının azalmasına ve böylece matematiğin kavramsal ve çok kültürlü yapısının tartışılmasına yardımcı olacağını ifade etmişlerdir. Matematik dersinde matematik tarihine yer veren araştırmaların neredeyse tamamının da (Albayrak, 2011; Baki ve Gürsoy, 2018; Başıüyük, 2018; Canady, 1983; Ersoy, 2015; Göker, 1997; Gürsoy, 2010; Karakuş, 2009; Kaşıkçı, 2015; Lit, Siu ve Wong, 2001; Jankvist, 2009; Özcan, 2014; Özdemir ve Göktepe, 2012; Thomaidis ve Tzanakis, 2009; Tokay, 2019; Tözlüyurt, 2008; Varol, 2019; Yenilmez, 2011) öğrencilerin matematik tarihi uygulamalarıyla derse karşı tutumlarında, matematik dersi başarılarında, yaratıcılıklarında (Ay, 2019), derse ilişkin ilgi ve motivasyonlarında (Mersin, 2019) pozitif yönde artş̧lar olduğu sonucuna ulaşmışlardır. Ayrıca Küçükoğlu'nun (2019) çalışmasında öğrencilerin matematik tarihi ile zenginleştirilmiş öğretim ortamında matematiğin tarihsel gelişimini ve doğasını daha iyi kavradıkları görülmüştür. McBride ve Rollins (1977) öğrencilerin çoğuna göre matematik sabit, değişmez, bir takım formül ve kurallardan ibaretken, matematik tarihi etkinliklerinin kullanıldığı uygulamalı derslerden sonra öğrencilerin matematiksel problemlerin sonuçlarına ulaşmak için birden fazla yolların olabildiğine, matematiğin yalnızca formüllerden oluşmayıp gelişen ve geliştiren bir bilim olduğuna dair söylemlerde bulunduklarını belirtmiş̧tir. Tzanakis ve Arcavi (2000) ise matematik tarihinin yer aldığı matematik derslerinin öğrenmeyi kolaylaştıracağını, matematiğin doğası ile öğrencilerin bakış açısını geliştireceğini, matematiğe ilişkin duyuşsal eğilimlerini pozitif olarak etkileyeceğini; ayrıca öğretmenlerin de öğretim repertuarlarını zenginleştireceğini matematiğin kültürel ve insan ürünü bir bilim olması bağlamında belirtmiştir. Gulikers ve Blom (2001), Tzanakis ve Arcavi (2000) ve Fried'un (2001) matematik eğitiminde matematik tarihinin kullanımına yönelik gerekçeleri Şekil 1'deki gibidir. 


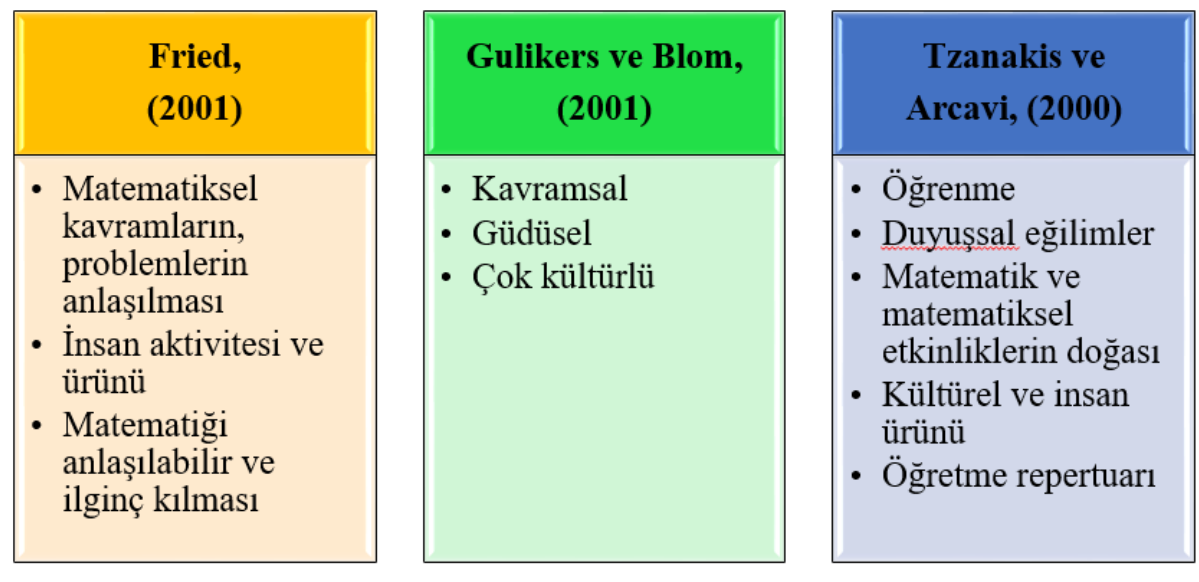

Şekil 1. Matematik Tarihinin Kullanım Nedenleri

Siu ve Tzanakis (2004) matematik tarihinin matematik öğretiminin ayrı bir parçası olarak değil de, bütünleşik ve doğal bir bölümü olarak ele alınması gerektiğini savunmuştur. Sanat tarihinin sanattan ayrı düşünülmesinin mümkün olmaması gibi, matematik tarihinin matematikten ayrı düşünülmesi olanaksızdır (Fauvel ve Van Maanen, 2002). Söz konusu olumlu savunmalara ve sonuçlara rağmen, matematik tarihinin matematik öğretiminde kullanımına yönelik yapılan çalışmalar inceleme ve küçük gruplar üzerinde uygulamalar düzeyinde kalmaktadır. 1970'li yıllardan bu yana, matematik tarihinin matematik eğitimi için öneminde söz eden çalışmalar alanyazında yer almaktadır. Günümüzde de başta matematik öğretimine dünya çapında rehberlik ederek yön veren Ulusal Matematik Öğretmenleri Konseyi (National Council of Teachers of Mathematics [NCTM]) olmak üzere, Tarih ve Matematik Eğitimi İlişkisi Üzerine Uluslararası Çalışma Grubu (International Study Group on the Relationship between the History and Pedagogy of Mathematics [HPM]) ve Amerika Matematik Derneği (Mathematical Association of America) gibi kurumlar tarafından da matematik tarihinin matematik öğretiminde kullanımı teşvik edilmektedir (Baş, 2019; Fried, 2001; Gençkaya, 2018). Uluslararası değerlendirmelerde çoğunlukla ilk sıralarda bulunan Hong Kong matematik öğretim programında matematik tarihinin kullanımı konusuna özel olarak değinmiştir (Başıbüyük, 2018). Ayrıca Çin, Almanya, Polonya ve Portekiz gibi ülkelerin öğretim programlarında da matematik tarihine yer verilmesi konusunda destekleyici açılamalar mevcuttur (Fauvel ve Maanen, 2002). 2005 yılı itibariyle yapılandırmacı yaklaşımları öğretim programına dâhil eden Milli Eğitim Bakanlığı'nın 2020 yılına kadar 2009, 2013 ve 2018 yıllarında yayınladığı (İlhan ve Aslaner, 2019) yeni öğretim programlarına bakıldığında da, 2009 yılı matematik dersi öğretim programında öğrencilerin matematiğin tarihsel süreçte nasıl geliştiğini, insan düşüncesinin gelişiminde nasıl bir rol oynadığını ve diğer bilim dallarına ne şekilde yararlar sağladığını anlayabilmelerine katkı sağlamanın genel amaçları içerisinde olduğu ifade edilmiştir. Programda matematik tarihinin öneminden söz edilmekle kalınmamış, olasılık, rasyonel sayılar, saat, para, geometrik cisimler ve ölçme gibi birçok kavramın tarihine yönelik etkinlik örneklerine yer verilmiştir. (MEB, 2009). Daha sonra ortaya konan 2013 yılı matematik dersi öğretim programında ise ilginç anekdotlar, önemli kişiler ve bu kişilerin matematiğe katkılarını içeren matematik tarihinin matematik derslerini öğrenciler için daha anlamlı hale getireceğinden söz edilmiştir. Ancak 2018 yılı ortaokul matematik dersi öğretim programında matematik tarihinden neredeyse hiç söz edilmemiştir. Matematik tarihinin matematik öğretiminde kullanımına yönelik son yıllarda yapılmış olan çalışmaların yoğunluğuna ve bu çalışmaların bilimsel bulgularıyla ortaya konmuş olumlu sonuçlara bakıldığında (Ay, 2019; Başıüyük, 2018; Bütüner, 2020; Furinghetti, 2019; Küçükoğlu, 2019; Mersin, 2019; Tokay, 2019; Varol, 2019) ortaokul matematik öğretim programında matematik tarihine yeterince yer verilmemesi dikkat çekicidir. Öğretim programına ilişkin durum bu şekilde iken, matematik tarihini öğrencilere ulaştırabilecek kaynakların başında gelen matematik ders kitaplarındaki durumunun da incelenmesi gerekebilir. Ders kitaplarının öğrencilerle öğretmenler arasında bir köprü görevi görmesi açısından öğretim ortamları için en mühim kaynaklardan biri olduğu söylenebilir (Mullis ve ark., 2012). Ayrıca alanyazındaki birçok araştırmanın da ortaya koyduğu üzere (Fan ve Kaeley, 2000; Li, Chen \& Kulm, 2009; Li ve Zhang, 2009; Stein, Remillard ve Smith, 2007) ders kitapları öğrencilerin öğretmenleri ile bağlarını kuvvetlendirerek öğrenme ve öğretme ortamlarının etkililiğini arttırmada kayda değer bir öneme sahiptir. Alajmi, (2012), Robitaille ve Travers (1992) ve Törnroos (2005) yaptıkları incelemelerde matematik ders kitaplarının başarı ve öğrenme çıktıları bağlamında ders içeriklerinin tasarlanması ve sunulmasında ve öğrenciler için verilen ders içi/dışı etkinliklerin kalitesinde göz ardı edilemez bir değerinin olduğunu ifade etmişlerdir. Matematik tarihinin matematik derslerinde kullanımının önemine dair yapılan çalışmalar göz önünde bulundurulduğunda matematik tarihine ait ögelere matematik ders kitaplarında yer verilmesi, özellikle matematik tarihinin derslerde kullanımı açısından zayıf olan öğretmenlerin öğretim ortamlarında matematik tarihini daha sık kullanmalarına yardımcı olacaktır (Fried, 2001). 
Matematik tarihinin matematik ders kitaplarında kullanılma durumlarını inceleyen çalışmalar (Baki ve Bütüner, 2013; Erdoğan, Eşmen ve Fındık, 2015; İncıkabı, Kepçeoğlu ve Küçükoğlu, 2017; Tan Şişman ve Kirez, 2018) incelendiğinde, bu çalışmaların son ortaokul matematik öğretim programına (MEB, 2018) göre hazırlanan kitaplar üzerinde yapılmadığı ve sadece mevcut durumu ortaya koymakla sınırlı kaldığı söylenebilir. Matematik tarihinin matematik eğitiminde kullanımının önemine dair yapılan çalışmalar güncelliğini korumasına rağmen, güncel öğretim programına bu önemin ne derece yansıdı̆̆ının da incelenmesi gerekmektedir. Bu araştırmada yapılan çalışmalardan farklı olarak son öğretim programına uygun olarak hazırlanmış ders kitapları incelenecek ve ayrıca hangi sınıfta hangi ünitede hangi kazanım için hangi matematik tarihi örneklerinin kullanılabileceğine yönelik önerilerde bulunulacaktır. Bu bağlamda çalışmada 2019-2020 eğitim öğretim yılında Milli Eğitim Bakanlığı tarafından MEB'e bağlı ortaokullarda okutulmak üzere dağıtılan Matematik ders kitaplarında matematik tarihinin kullanılma durumuna ilişkin ortaokul matematik ders kitaplarında yer alan matematik tarihi ögelerinin,

$\checkmark$ İçeriklerinin sınıf seviyelerine göre dağılımları nasıldır?

$\checkmark$ Kitaplardaki konumlarına göre dağılımı nasıldır?

$\checkmark$ Kullanım yollarına göre dağılımı nasıldır?

$\checkmark$ Öğrenme alanlarına göre dağılımı nasıldır?

$\checkmark$ Ortaokul matematik dersi ögrrenme programına göre sınıf seviyelerine uygun olarak önerilebilecek matematik tarihi ögeleri neler olabilir? sorularına yanıt aranmıştır.

\section{Yöntem}

2018 öğretim programına göre düzenlenmiş ortaokul matematik ders kitaplarının içerdiği matematik tarihi ögeleri (MTÖ) bağlamında incelendiği bu çalışmada nitel araştırma desenlerinden betimsel yöntem kullanılmış ve araştırma sorularına uygun veriler doküman analizi yoluyla toplanmıştır. Doküman analizi üzerinde çalışılmak istenen durumlara ilişkin verilerin yer aldığ 1 yazılı materyallerin kapsam ve içeriğine yönelik analiz edilmesidir (Yıldırım ve Şimşek, 2013).

\subsection{Veri Toplama Aracı / Araçları}

Doküman incelemesinde 2019-2020 eğitim öğretim yılında, Talim ve Terbiye Kurulu Başkanlığ tarafından 2018 yılı itibariyle kabul edilen ortaokul matematik dersi öğretim programına uygun olarak ortaokul 5-8. sınıflarda okutulmak üzere MEB tarafından hazırlanmış olan matematik ders kitapları kullanılmıştır. Her sınıf düzeyine ait hazırlanmış olan birden fazla ders kitabı olmasına rağmen araştırmanın yapıldığı ilçedeki okullarda dağıtılan kitaplara odaklanılmıştır. Araştırma kapsamında yer verilen ders kitaplarına ait detaylar Şekil 2'de gösterilmiştir.

\begin{tabular}{|c|c|c|}
\hline Sinıf & Yayınevi & İç Kapak Açıklaması \\
\hline 5. Sinif & $\begin{array}{l}\text { SDR Dikey } \\
\text { Yayıncılık }\end{array}$ & 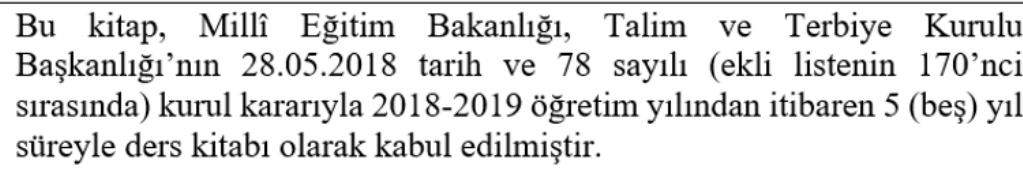 \\
\hline 6. Sinif & Öğün Yayınları & $\begin{array}{l}\text { Bu kitap, Millî Eğitim Bakanlığı Talim ve Terbiye Kurulu Başkanlığının } \\
\text { 18.04.2019 tarihli ve } 8 \text { sayılı (ekli listenin 173'üncü sırasında) kurul } \\
\text { kararı ile 2019-2020 Öğretim Yılından itibaren } 5 \text { (beş) yıl süreyle ders } \\
\text { kitabı olarak kabul edilmiştir. }\end{array}$ \\
\hline 7. Sinif & EkoYay Yayıncılık & $\begin{array}{l}\text { Millî Eğitim Bakanlı̆̆ Talim ve Terbiye Kurulunun } 18.04 .2019 \text { tarih ve } \\
8 \text { sayılı kurul (ekli listenin 163'üncü sırasında) kararı ile 2019-2020 } \\
\text { öğretim yılından itibaren } 5 \text { (beş) yıl süre ile Ders Kitabı olarak kabul } \\
\text { edilmiştir. }\end{array}$ \\
\hline 8. Sinif & Kök Yayınları & $\begin{array}{l}\text { Millî Eğitim Bakanlığı Talim ve Terbiye Kurulu Başkanlığının } \\
28.05 .2018 \text { tarih ve } 78 \text { sayılı kararıyla 2018-2019 öğretim yılından } \\
\text { itibaren } 5 \text { (beş) yıl süreyle ders kitabı olarak kabul edilmiştir. }\end{array}$ \\
\hline
\end{tabular}

Şekil 2. Araştırma Kapsamında İncelenen Ders Kitapları, Yayınevleri ve İç Kapak Açıklamaları 


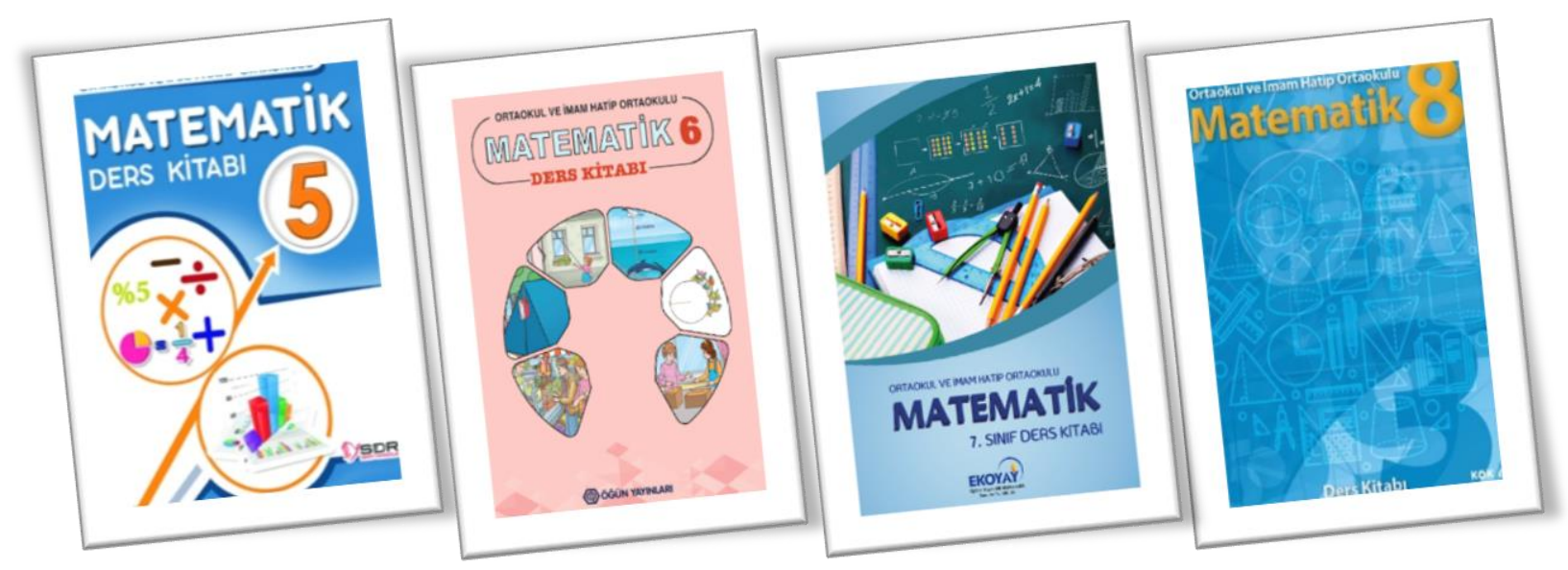

Şekil 3. Araştırma Kapsamında İncelenen Ders Kitapları

\subsection{Verilerin Analizi}

Araştırmada yer verilen ders kitapları incelenirken "MTÖ içeriklerine, sınıf seviyelerine, kitaplardaki konumlarına, kullanım yollarına ve öğrenme alanlarına" göre dağılımları ele alınmıştır.

Veri analizinde özellikle Erdoğan ve arkadaşlarının (2015) önerdiği sınıflandırmaya uygun kategoriler kullanılmıştır. Bu kategoriler matematik tarihinin matematik kitaplarından ne şekilde kullanıldığını belirlemek üzere dört başlıkta ele alınmış ve Şekil 3'te gösterilmiştir. Daha sonra ders kitapları Mersin ve Durmuş'un (2018) içerik sınıflaması ve Tzanakis ve Arcavi'nin (2000) kullanım yollarına göre tekrar içerik analizlerine tabi tutulmuşlardır. Mersin ve Durmuş (2018) MTÖ içeriklerini "bilim insanlarının hayatı", "eski matematiksel yöntemler", "matematiksel kavramların tarihsel gelişim süreci" ve "matematik dışı bir ögenin tarihsel gelişimi" şeklinde sınıflandırmışlardır. Tzanakis ve Arcavi (2000) ise bu ögelerin kullanım şekillerini "tarihsel ufak parçalar", deneysel matematik etkinlikleri", "internet", "mekanik araçlar", "çalışma yaprakları", "tarihsel metinler üzerine dayalı araştırma projeleri", "tarihsel problemler", "filmler ve diğer görseller", "oyunlar", "okul dışı deneyimler", "matematikçilerin yaptıkları hatalardan yararlanma" ve "birincil kaynaklar" olarak belirlemişlerdir. Ayrıca ders kitaplarında kullanılan tarihsel ögelerin ne derece kullanıldığını, matematik tarihi ile ilgili durumları nasıl bir içerikle, hangi kullanım yollarıyla, dersin hangi aşamasında, hangi öğrenme alanında ele aldığı ve sınıf düzeylerine göre bu durumun nasıl değiştiğiyle ilgili kodlamalar 3 farklı uzman tarafindan yapılmıştr. Ulaşılan bulgular yüzde, frekans tabloları, grafikler ve örnek resimler ile sunulmuş̧tur.

\begin{tabular}{ll}
\hline Tarihsel notlar & $\begin{array}{l}\text { Tarihler, biyografiler, anekdotlar, sembollerin ve kelimelerin kökeni gibi } \\
\text { bilgilerin verildiği notlar (Sayıların eski medeniyetlerde nasıl ifade edildiği, pi } \\
\text { sayısının tarihsel gelişimi, vb.). }\end{array}$ \\
$\begin{array}{l}\text { Matematiğin kullanım } \\
\text { alanlarına ilişkin notlar }\end{array}$ & $\begin{array}{l}\text { Matematiğin tarihsel süreçte ortaya çıkan çeşitli kullanım alanlarının açılkandığı } \\
\text { notlar (İlkel sayı sembollerinin sayma için kullanılması, Fibonacci sayılarıyla } \\
\text { doğadaki düzenin okunması, vb.). }\end{array}$ \\
$\begin{array}{l}\text { Tarihsel notlarla birlikte } \\
\text { uygulamalar }\end{array}$ & $\begin{array}{l}\text { Matematik tarihine ilişkin notların çeşitli örnek veya uygulamalarla birlikte } \\
\text { açklanması (kesirlerin nasıl yazıldığının gösterilmesi, sayı sembollerinin nasıl } \\
\text { okunduğunun gösterilmesi, vb.). }\end{array}$ \\
$\begin{array}{l}\text { Öğrencinin okul dışı } \\
\text { çalışmalarında yer alan } \\
\text { tarihsel ögeler }\end{array}$ & $\begin{array}{l}\text { Matematik tarihi içeren projeler, performans görevleri gibi okul dışı çalışmalara } \\
\text { yönelik öğeler (Bir matematikçinin çalışmalarının incelenmesi, bir kavramın } \\
\text { tarihçesiyle ilgili araștırma yapılması, vb.) }\end{array}$ \\
\hline
\end{tabular}

Şekil 3. Erdoğan, Eşmen ve Findık'a (2015) göre sınıflandırma ve açıklamaları

Erdoğan ve arkadaşları (2015) kendi araştırmalarında matematik tarihi ögesini, "matematik tarihinin uğraş alanları ile ilgili açıkça bilgi taşıyan nesneler" şeklinde ele aldıkları görülmüştür. Bu anlamda hangi ögenin hangi içeriğe uygun olduğunun anlaşılması için Şekil 3, 4, 5, 6’da bazı örnekler verilmiştir. 


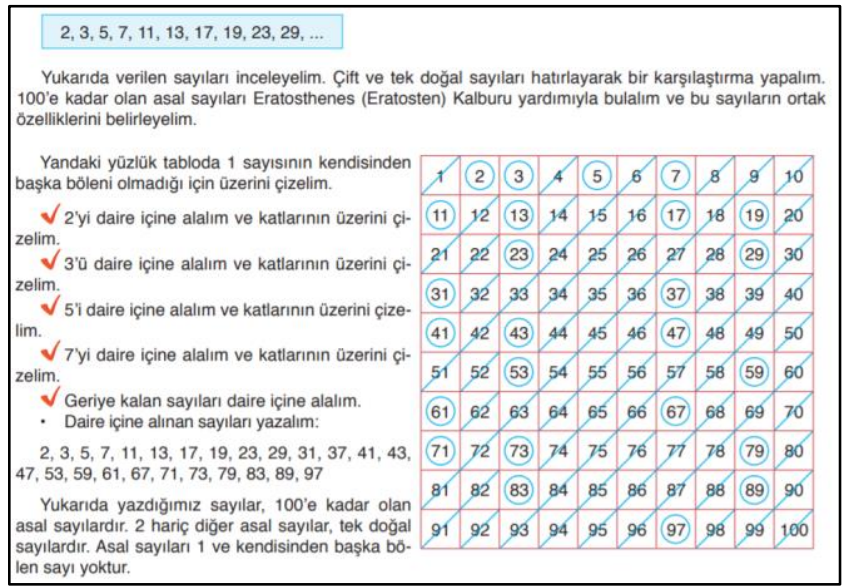

Şekil 4. Tarihsel öge olarak değerlendirilmeyen bir öge (Öğün Yayınları 6. sınıf, s.48)

Şekil 4 'te altıncı sınıf matematik ders kitabında yer alan Eratosthenes Kalburu etkinliği incelendiğinde hiçbir tarihi veriye yer verilmediği görülmüş ve bu tip ögeler tarihsel öge olarak kabul edilmemiştir. Eratosthenes'in milattan önce 250 'li yıllarda yaşadığı ve söz konusu kalburun sadece 1'den 100'e kadar değil, istenilen büyüklükteki herhangi bir sayıya kadar asal sayıları bulmaya yaradığına değinilmesi durumunda tarihsel öge olarak kabul edilebilirdi.

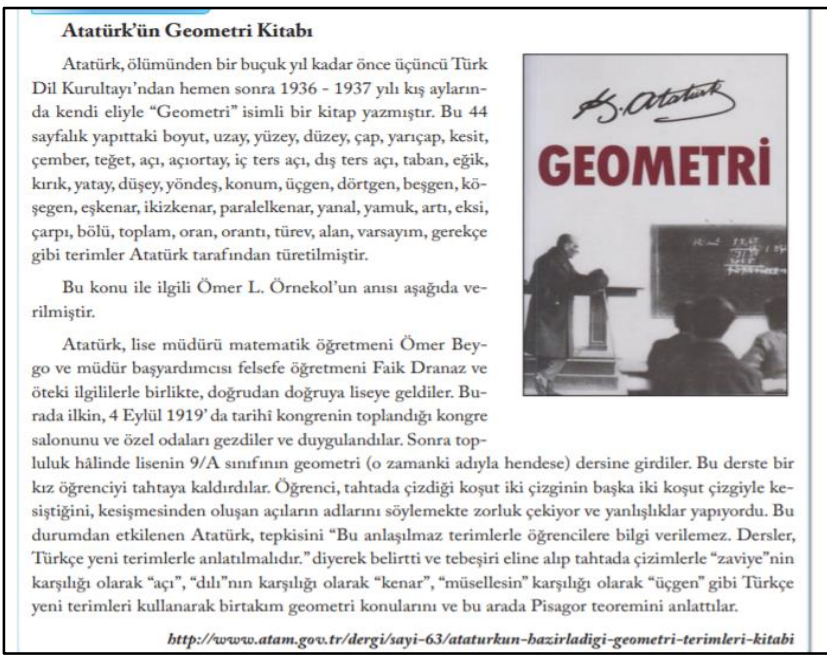

Şekil 5. Tarihsel Not olarak kabul edilen bir öge (EkoYay Yayınları 7. Sınıf, s. 173)

Şekil 5'teki gibi, matematikle doğrudan bağlantısı kurulmayarak ve kendisinden sonra herhangi bir soru problem vb sorulmayarak sadece bilgi notu veya okuma metni şeklinde yer verilmiş bilgiler "tarihsel not" kategorisinde değerlendirilmiştir.

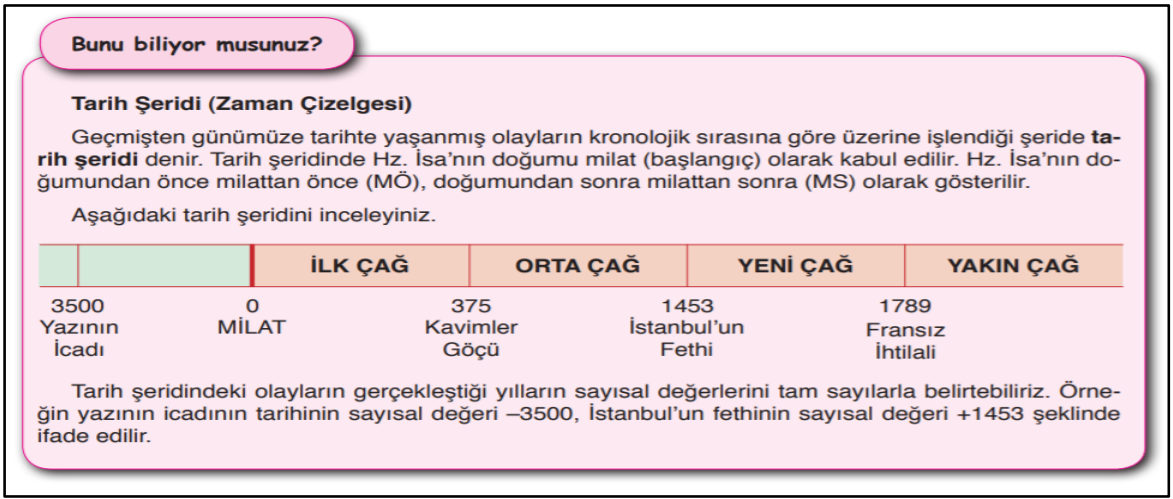

Şekil 6. Matematiğin Kullanım Alanlarına İlişkin olarak kabul edilen bir öge (Öğün Yayıncılık 6. Sınıf, s. 85)

Şekil 6'daki gibi matematiğin kullanıldığı diğer alanların ifade edildiği notlar, bilgiler "matematiğin kullanım alanlarına ilişkin notlar" kategorisinde değerlendirilmiştir. Örneğin yine 7. Sınıf matematik ders kitabında yer alan Türk Bayrağı ölçülerinin kabul ediliş tarihinin ve sabit oranların verildiği bir başka bilgi notu da bu kapsamda değerlendirilmiştir. 


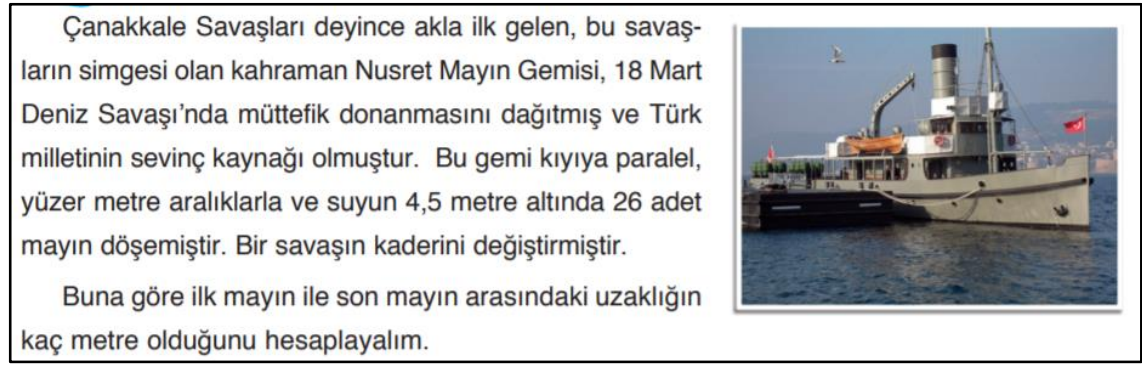

Şekil 7. Tarihsel Notlarla Birlikte Uygulamalar olarak kabul edilen bir öge (SDR Yayınları 5. Sınıf, s.235)

Şekil 7 incelendiğinde, Çanakkale Savaşı'nın tarihi ile ilgili bir bilgi verilmiş ve ardından bu bağlamda bir problem sorulmuştur. Bu şekilde kurgulanmış tarihsel notlar, "tarihsel notlarla birlikte uygulamalar" kategorisinde yer alacaktır.

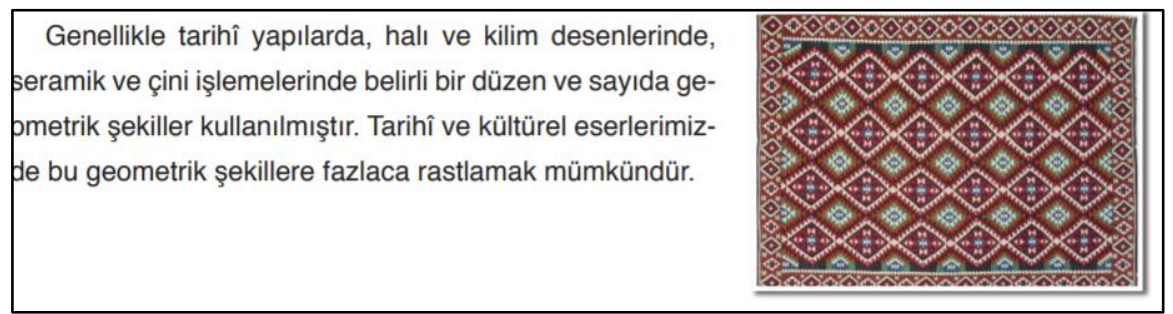

Şekil 8. Öğrencinin okul dışı çalışmalarında yer alan tarihsel ögelere örnek (SDR Yayınları 5. Sınıf, s21)

Ders kitaplarında yer alan tarihi öğelerin öğrencilerin okul dışı çalışmalarında karşılarına çıkabileceği bilgi notları, resimler ve metinler şeklinde kullanılması "okul dışı çalışmalarında yer alan tarihsel ögeler" kategorisinde değerlendirilmiştir. Öğrenci Şekil 8'deki gibi bir bilgi notu sayesinde günlük hayatında karşısına çıkan halı, kilim, seramik ve çini gibi şekillerde örüntüleri fark edecektir. Herhangi bir matematik kavramının tarihsel gelişiminin incelenmesi veya ünlü bir matematikçinin matematiğe katkılarının incelenmesiyle ilgili ödev, proje performans görevlerinin verildiği notlar da bu kategoride yer almıştır.

Veri analizlerine başlamadan önce 3 uzman hangi ögenin hangi içerikteki ve hangi kullanımdaki MTÖ'ye uygun olarak ele alınacağına karar vermek ve görüş birliği sağlamak için incelemeler yapmıştır. Araştırmanın güvenirliği Miles ve Huberman'ın (1994) geliştirdiği formül (Güvenirlik: [(Görüş Birliği)/(Görüş Birliği + Görüş Ayrılı̆̆ı)x100] ile belirlenmiştir. Bu formül uzmanların görüşleri arasındaki uyum oranını hesaplamaya yarar ve bu güvenirlik için alt sınır 0,7'dir (Yıldırım \& Şimşek, 2008). Bu araştırmada ön görüşler sonucu 3 uzman ve araştırmacının uyum yüzdesi 0,83 olmasına rağmen görüş birliğinin sağlanamadığı maddeler için uzmanlar bir araya getirilerek bir tartışma ortamı oluşmuş ve nihai karara varılmıştır. Ayrıca incelemeler sonrasında uzman desteği alınarak ortaokul matematik dersi öğrenme programına göre sınıf seviyelerine uygun olarak önerilebilecek matematik tarihi ögelerinden oluşan tablolar hazırlanmıştır. Önerilen Matematik Tarihi Öğelerine (ÖMTÖ) araştırma eklerinde yer verilecektir.

\section{Bulgular}

Bu bölümde incelenen ders kitaplarında yer verilen 27 MTÖ’nün (Ek1) içeriklerine, kullanım yollarına, kitaplardaki konumlarına ve öğrenme alanlarına göre dağılımlarının yer aldığı tablolara ve açıklamalara yer verilecektir.

Tablo 1. Ögelerin Erdoğan ve arkadaşlarına (2015) göre MTÖ içeriklerinin dağılımları

\begin{tabular}{lccccc}
\hline Kategoriler & 5. Sınıf & 6. Sıııf & 7. Sınıf & 8. Sınıf & Toplam \\
\hline Tarihsel notlar & 5 & 1 & 3 & 4 & 13 \\
Matematiğin kullanım alanlarına ilişkin notlar & 1 & 1 & 1 & 2 & 5 \\
$\begin{array}{l}\text { Tarihsel notlarla birlikte uygulamalar } \\
\text { Öğrencinin okul dışı çalışmalarında yer alan }\end{array}$ & 5 & 3 & - & - & 8 \\
tarihsel ögeler & 1 & - & - & - & 1 \\
\hline Toplam & 12 & 5 & 4 & 6 & 27 \\
\hline
\end{tabular}

Ders kitaplarındaki MTÖ içeriklerine göre dağılımlarının verildiği Tablo 1 incelendiğinde tarihsel ögelerin en fazla kullanıldığı sınıf seviyesinin 5. Sınıf $(n=12)$, en fazla yer alan kategorinin tarihsel notlar $(n=13)$ olduğu görülmektedir. Öğrencinin okul dışı çalışmalarında yer alan tarihsel ögelere neredeyse hiç verilmediği $(n=1)$, tarihsel notlarla birlikte uygulamalara ise sadece beşinci $(n=5)$ ve altıncı $(n=3)$ sinıf seviyesinde yer verildiği dikkati çekmektedir Bu durumun öğrencilerin yaş seviyesinin büyüdükçe uygulamadan ziyade teoriye ağırlık 
verilmesi şeklinde yorumlanabilir. Ayrıca matematiğin kullanım alanına ilişkin notların beklenenden az olduğu $(\mathrm{n}=5)$ söylenebilir.

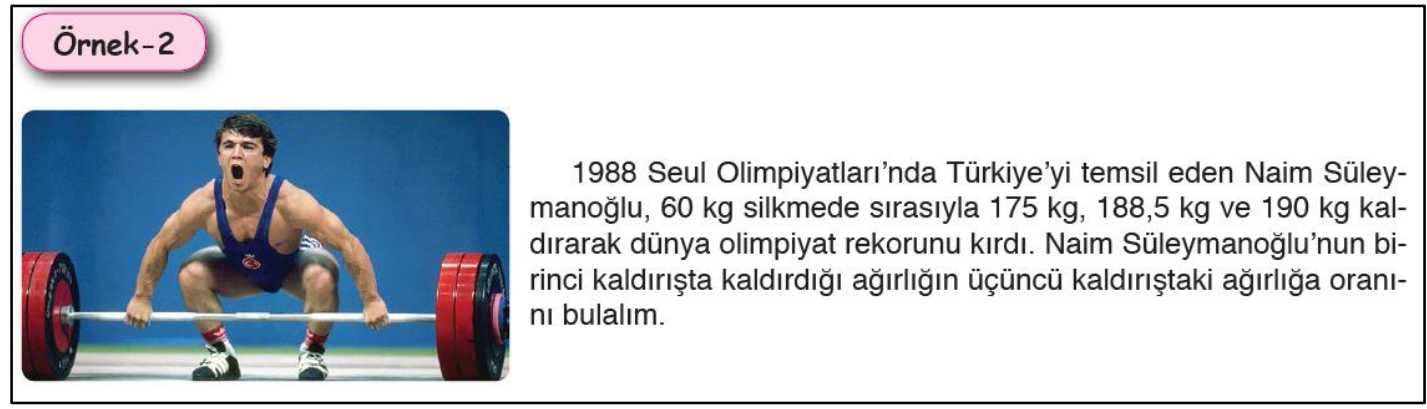

Şekil 9. Tarihsel notlarla birlikte uygulamalara örnek (Öğün Yayıncılık 6. Sınıf, s. 174)

Tablo 2. Ögelerin Mersin ve Durmuş’a (2018) göre MTÖ içeriklerinin dağılımları

\begin{tabular}{|c|c|c|c|c|c|}
\hline İçerikler & 5. Sinif & 6. Sinif & 7. Sinif & 8. Sinif & Toplam \\
\hline Bilim İnsanlarının Hayatı & - & - & - & 1 & 1 \\
\hline $\begin{array}{l}\text { Eski Matematiksel } \\
\text { Yöntemler }\end{array}$ & - & - & - & 1 & 1 \\
\hline $\begin{array}{l}\text { Matematiksel Kavramların } \\
\text { Tarihsel Gelişim Süreci }\end{array}$ & 2 & 1 & 2 & 4 & 9 \\
\hline $\begin{array}{l}\text { Matematik Dışı Bir Ögenin } \\
\text { Tarihsel Gelişimi }\end{array}$ & 10 & 4 & 2 & - & 16 \\
\hline Toplam & 12 & 5 & 4 & 6 & 27 \\
\hline
\end{tabular}

MTÖ’nün Mersin ve Durmuş'un (2018) sınıflandırmasındaki içeriklerin yer aldığı Tablo 2'ye göre, tarihin çoğunlukla matematik dışı bir ögenin tarihsel gelişimi $(n=16)$ şeklinde kullanıldığı görülmüştür. Tekerleğin bulunması, televizyonun ortaya çıkışı, termometrenin keşfi gibi bilgi notları bu başlık altında ele alınmıştır. Bunun yanında pi'nin bulunması, tangramın tarihi serüveni, Atatürk’ün yazdığı geometri kitabı, kareköklü sayıların ortaya çıkışı gibi ögeler matematiksel kavramların tarihsel gelişim sürecine $(\mathrm{n}=9)$ dâhil edilmiştir. Bunun yanında 8. Sınıf ders kitabında karşılaşılan Pisagor'un tanıtılması bilim insanın hayatı (n=1) ve Sümerlerin kullandıkları 601ık sistemin anlatıldığ 1 bilgi notu ise eski matematiksel yöntem ( $\mathrm{n}=1)$ olarak ele alınmıştır. Bilim insanlarının hayatlarına, eski matematiksel yöntemlere veya matematiksel kavramların tarihsel gelişim süreçlerine dair ögelere az sayıda yer verilmesinden hareketle ortaokul matematik ders kitaplarında matematik tarihinden yeterince yararlanılmadı̆̆

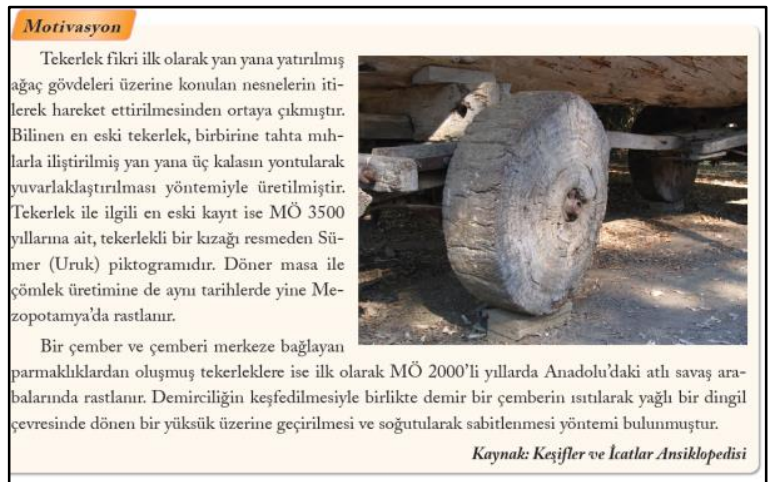

Şekil 10. Matematik Dışı Bir Ögenin Tarihsel Gelişimine örnek (Eko Yayıncılık 7. Sınıf, s.229)

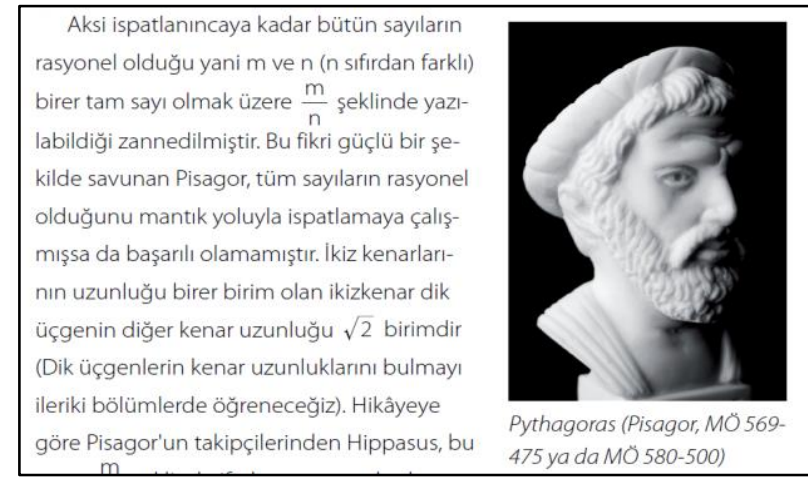

Şekil 11. Matematiksel Kavramların Tarihsel Gelişim Sürecine örnek (Kök Yayıncılık 8. Sınıf, s. 58)

Tablo 3. Tzanakis ve Arcavi’nın (2000) kullanım yollarına göre MTÖ dağılımı

\begin{tabular}{lccccc}
\hline Kullanım Yolu & 5. Sınıf & $\begin{array}{c}\text { 6. } \\
\text { Sinıf }\end{array}$ & 7. Sinıf & 8. Sinıf & Toplam \\
\hline Tarihsel ufak parçalar & 11 & 3 & 4 & 4 & 22 \\
Deneysel matematik etkinlikleri & 1 & 1 & - & - & 2 \\
İnternet & - & 1 & - & - & 1 \\
Çalışma yaprakları & - & - & - & - & - \\
Tarihsel Problemler & - & - & - & - & 1 \\
Mekanik Araçlar & - & - & - & 1 & \\
Tablo 3'ün devamı & & & & &
\end{tabular}




\begin{tabular}{lccccc}
\hline Kullanım Yolu & 5. Sınıf & $\begin{array}{c}6 . \\
\text { Sinıf }\end{array}$ & 7. Sınıf & 8. Sınıf & Toplam \\
\hline $\begin{array}{l}\text { Tarihsel metinler üzerine dayalı } \\
\text { araştırma projeleri }\end{array}$ & - & - & - & - & - \\
$\begin{array}{l}\text { Oyunlar } \\
\text { Filmler ve diğer görseller }\end{array}$ & - & - & - & - & - \\
Okul dışı deneyimler & - & - & - & - & - \\
Birincil Kaynaklar & - & - & - & - & - \\
Matematikçilerin yaptıkları & - & - & - & 1 & 1 \\
hatalardan yararlanma & - & - & - & - & - \\
\hline Toplam & 12 & 5 & 4 & 6 & 27 \\
\hline
\end{tabular}

Tablo 3'te görüldüğ̈̈ gibi ortaokul matematik ders kitaplarında tespit edilen 27 MTÖ'nün 22'sinin tarihsel ufak parçalar, 2'sinin deneysel matematik etkinlikleri, 1'inin öğrenciyi araştırmaya yönlendiren internet taraması, 1'inin mekanik araçlar, 1'inin ise birincil kaynaklar şeklinde kullanıldığ görülmektedir. Tarihsel problemlere, tarihsel metinlere bağlı araştırma problemlerine, oyunlara, film vb görsellere, okul dış1 deneyimlere, birincil kaynaklara ve matematikçilerin yaptıkları hatalara ise hiç değinilmemiştir. Buradan hareketle ders kitaplarında kullanılan MTÖ sayısının az olmasının yanında çeşitliliğinin de yeterli olmadığı söylenebilir.

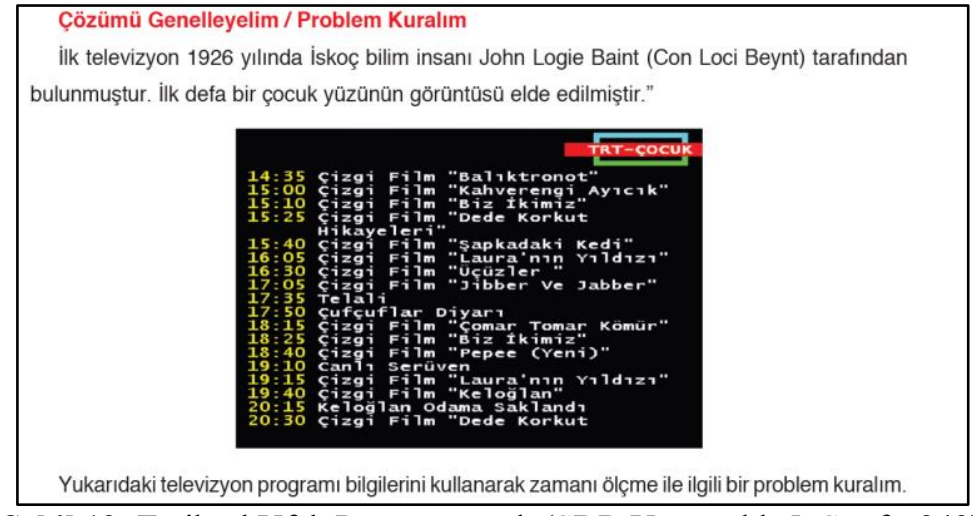

Şekil 12. Tarihsel Ufak Parçaya örnek (SDR Yayıncılık 5. Sınıf s.249)

Tablo 4. Kitaplardaki konumlarına göre MTÖ dağılımı

\begin{tabular}{lccccc}
\hline Kitaplardaki Konumlar & 5. Sinıf & 6. Sinıf & 7. Sinıf & 8. Sinıf & Toplam \\
\hline Konuya Giriş & 6 & 2 & 2 & 5 & 15 \\
$\begin{array}{l}\text { Konu İçinde } \\
\begin{array}{l}\text { Değerlendirme ve Konu } \\
\text { Sonu }\end{array}\end{array}$ & 3 & 1 & 1 & 1 & 6 \\
\hline Toplam & 3 & 2 & 1 & - & 6 \\
\hline
\end{tabular}

Osmanlı Devleti 23 Aralık 1876 tarihinde
1. Meşrutiyet'in ilanı ile parlamenter sisteme
geçmişti. Türkiye tarihinin ilk seçimleri gü-
nümüzden 142 yıl önce Osmanlı Devleti'nin
parlamenter sisteme geçtiği 1876 yılında ya-
pılmıştı. Meclisi Mebusanın 130 üyeliği için
yapılan bu seçim sonunda ilk meclis 69 Müs-
lüman ve 46 gayrimüslim olmak üzere toplam
115 milletvekili ile Dolmabahçe Sarayı'ndaki
büyük salonda yapılan törenle açılmıştı.

Şekil 13. Konunun Giriş Kısmında Kullanılan bir öğe (SDR Yayıncılık 5. Sınıf, s. 216)

Kitaplardaki konumlarına göre MTÖ dağılımlarının yer aldığı Tablo 6incelendiğginde kitaplarda karşılaşılan 27 tarihî ögenin 15'inin konunun başlangıç bölümünde, 6'sının konu içerisinde, 6'sının ise konu sonunda ve değerlendirme aşamasında kullanıldığı görülmektedir. Bu durumdan hareketle çoğunlukla öğrencilerin güdülenmesi ve derse dikkatlerinin çekilmesi noktasında matematik tarihinden yararlandığı söylenebilir. 
Tablo 7. Öğrenme alanlarına göre MTÖ dağılımı

\begin{tabular}{lccccc}
\hline Öğrenme Alanları & 5. Sınıf & 6. Sınıf & 7. Sınıf & 8. Sınıf & Toplam \\
\hline Sayılar ve İşlemler & 4 & 4 & 1 & 3 & 12 \\
Cebir & - & - & - & - & - \\
Geometri ve Ölçme & 2 & 1 & 3 & 1 & 7 \\
Veri İşleme & 6 & - & - & - & 6 \\
Olasılık & - & - & - & 2 & 2 \\
\hline Toplam & 12 & 5 & 4 & 6 & 27 \\
\hline
\end{tabular}

Yeni ortaokul matematik öğretim programına göre Geometri ve Ölçme, Sayılar ve İşlemler ve Veri İşleme öğrenme alanlarına bütün seviyelerde yer verilmişken, Cebir öğrenme alanı 6. Sınıf itibari ile öğrencilerin karşısına çıkmakta, olasılık öğrenme alanına ise sadece 8 . Sınıfta yer verilmektedir. Bu bağlamda olasılık öğrenme alanı ile ilgili matematik tarihi ögeleriyle sadece 8. Sinıf $(n=2)$ matematik ders kitabında karşılaşılmıştır. Bunun yanında cebir öğrenme alanı ile ilgili hiçbir öğrenme seviyesinde MTÖ’ye yer verilmemiştir. Sayılar ve işlemler öğrenme alanı ile ilgili 5. sınıf seviyesinde 4, 6. sınıf seviyesinde 4, 7. sınıf seviyesinde 1 ve 8 . sınıf seviyesinde 3 ögeye rastlanmıştır. Bu anlamda matematik tarihinin en fazla kullanıldığ 1 öğrenme alanı sayılar ve işlemler $(n=12)$ öğrenme alanıdır. Veri işleme öğrenme alanında sadece 5. Sınıfta $(n=6)$ MTÖ’nin yer almış olması da dikkat çekmektedir. Ayrıca geometri öğrenme alanı ile ilgili 5. sınıf seviyesinde 2 , 6. sinif seviyesinde 1,7 . sinif seviyesinde 3 ve 8 . sinif seviyesinde 1 öge yer almaktadır. Matematik tarihinin yoğun kullanıldığı diğer bir öğrenme alanı da geometri $(n=7)$ öğrenme alanıdır. Bunun sebebi olarak ortaokul matematik dersi öğretim programında yer alan sayılar, işlemler ve geometri konularının tarihle ilişkilendirilmesinin öğrenci seviyesine daha uygun olduğu söylenebilir.

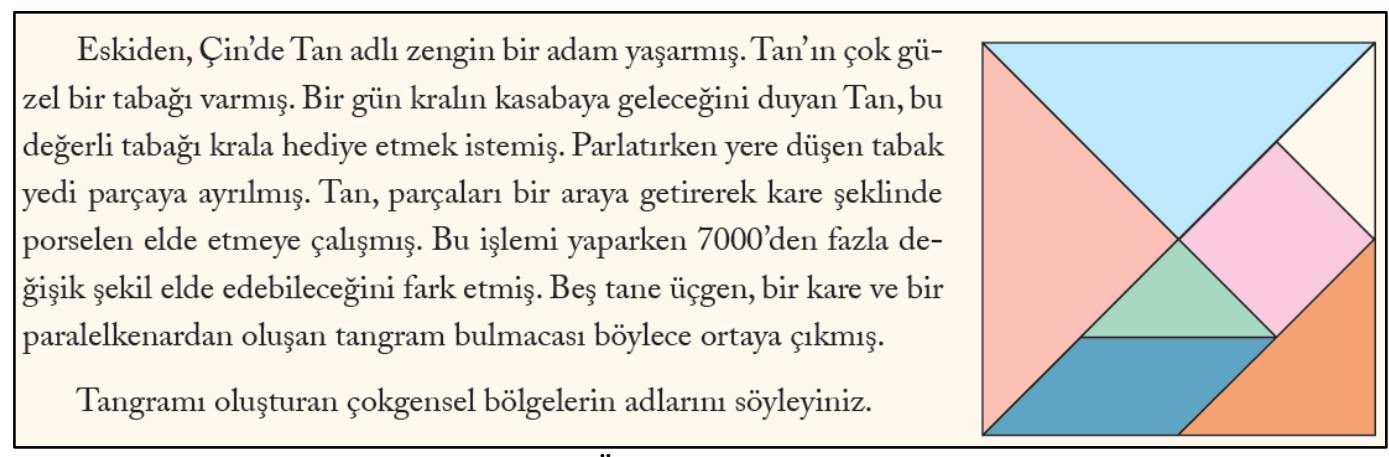

Şekil 14. Geometri ve Ölçme (EkoYayıncılık 7 Sınıf, s. 188)

\section{Tartışma ve Sonuç}

Ortaokul matematik ders kitaplarında, matematik tarihinin ne derece kullanıldı̆̆ını, matematik tarihi öğelerinin (MTÖ) nasıl bir içerikle, hangi kullanım yollarıyla, dersin hangi aşamasında, hangi ögrenme alanında ele aldığı ve tüm bu başlıkların sınıf düzeylerine göre nasıl değiştiğinin araştırıldığı bu çalışmada 2019-2020 eğitim-öğretim yılında kullanılan 4 ortaokul matematik ders kitabı incelenmiştir. Yapılan doküman incelemesi sonucunda 27 MTÖ tespit edilmiştir. Bu sayı kitap başına 6,5 MTÖ anlamına gelmektedir. Baki ve Bütüner (2013) matematik tarihi açısından 6, 7 ve 8. sınıf ders kitaplarını incelediği çalışmalarında 3 kitapta 19 MTÖ’ye rastlarken; Erdoğan, Eşmen ve Fındık (2015) 2013- 2014 yıllarında okutulan 7 ortaokul ders kitabını incelediğinde 27 MTÖ belirlemişlerdir. Bunun yanında İncıkabı ve arkadaşları (2019) 2016-2017 yıllarında kullanılan 8 matematik ders kitabını incelemişler ve 15 MTÖ’ye ulaşmışlardır. Yine Mersin ve Durmuş'un (2018) aynı yıllarda kullanılan ders kitaplarını inceledikleri çalışmalarında 4 kitaptan 19 öge ile karşılaştıklarını belirtmişlerdir. Tan Şişman ve Kirez (2018) ise 2015-2016 yıllarında okutulan 6 matematik ders kitabında 27 tarihsel ögeye yer verildiğini belirtmiştir. Yapılan çalışmalarla karşılaştırıldığında 2018 ortaokul matematik dersi öğretim programında hiçbir tarihsel bağlam tartışılmamasına rağmen kullanılan MTÖ sayısı her geçen yıl artış göstermiştir. Nicel olarak durum bu şekilde olsa da kullanılan tarihsel ögelerin matematikle ilişkisi bağlamında yetersiz olduğu söylenebilir.

İncelenen ders kitaplarında yer verilen MTÖ’nün kapsamının Erdoğan ve arkadaşlarına (2015) göre sınıflandırılması sonucunda tarihsel ögelerin en fazla kullanıldığı sınıf seviyesinin beşinci sınıf, en fazla yer alan kategorinin ise tarihsel notlar olduğu görülmektedir. Tarihsel notların matematikle ilişkisi olmayan bir takım tarihi bilgiler niteliğinde olması söz konusu kullanımın matematik tarihinin matematik eğitimine katkısı bağlamına uygun olmadığı söylenebilir. Öğrencinin okul dışı çalışmalarında yer alan tarihsel ögelere neredeyse hiç verilmediği $(\mathrm{n}=1)$, tarihsel notlarla birlikte uygulamalarlaysa sadece beşinci ve altıncı sınıf seviyesinde karşılaşılması dikkati çekmektedir. Bu durum öğrencilerin yaş seviyesinin büyüdükçe uygulamadan ziyade teoriye ağırlık verilmesi şeklinde yorumlanabilir. Bunun yanında matematĭgin kullanım alanına ilişkin notlara ayrılan bölümün yeterli olmadığı görülmüştür. Söz konusu bulgular matematik tarihinin kullanılması bağlamında 
matematik ders kitaplarının incelendiği diğer çalışmalarla (Baki ve Bütüner, 2013; Erdoğan ve ark., 2015; İncıkabı ve ark., 2017; Tan Şişman ve Kirez, 2018) benzerlik göstermektedir. Matematiğin günlük yaşamla ilişkisinin öneminin sık sık vurgulandığı (MEB, 2018) yapılandırmacı yaklaşıma uygun olarak hazırlanmış ders kitaplarında matematiğin okul dışı ortamlara ve günlük hayattaki kullanımına ilişkin tarihsel notlara yer verilmemesi dikkat çekicidir. Eski medeniyetler, gündelik gereksinimlerini karşılamak amacıyla çeşitli sayı sistemleri kullanmışlardır. Miktar ve ölçüleri belirtmek için kemikler kullanmışlar, bunlar üzerine atıkları çentikleri, bazen de taş ve odun parçalarını kullanarak hesaplamalar yapmışlardır (Krantz, 2006). Matematik tarihine yönelik çalışmalar (Burton, 2017; Cajori, 2014; Struik, 2011) incelendiğinde matematiğin süreç içerisinde büyüyüp gelişmesine günlük ihtiyaçların ne kadar katkısı olduğu görülebilir. Babil, Mısır, Maya Medeniyetlerinin, Çin, Hint, Yunan ve İslam toplumların matematiği nasıl kullandığını öğrenci seviyesine uygun şekilde belirten MTÖ'nün öğrencilerin dikkatlerini çekeceği ve derse ilişkin motivasyonlarına olumlu katkılar sunacağı (Başıüyük, 2018; Gulikers ve Blom, 2001; Mersin, 2019). Ayrıca matematik tarihinin matematik derslerinde kullanımının öğrenmeyi kolaylaştıracağı, öğrencide farklı bir bakış açısı geliştireceği, matematiği daha ilginç ve kavramsal hale getireceği, matematiğe yönelik duyuşsal eğilimleri de pozitif yönde etkilemesi (Fried, 2001; Tzanakis ve Arcavi, 2000) göz önüne alındığında ders kitaplarında daha fazla yer verilmesi gerektiği söylenebilir.

Matematik tarihi öğelerinin Mersin ve Durmuş'a (2018) göre yapılmış içerik sınıflandırmasında, karşılaşılan öğelerinin büyük bir kısmının matematik dlşı bir ögenin tarihsel gelişsimi şeklinde olduğu görülmüştür. Matematiksel kavramların tarihsel gelişim süreci kategorisinde de yeterli sayıda olmasa da bazı ögelerin yer aldığı söylenebilir. Ayrıca bilim adamlarının hayatına ve eski matematiksel yöntemlere ilişkin tarihî ögelere sadece bir kez olmak üzere sekizinci sınıf ders kitabında yer verilmiştir. Söz konusu ögelerin içeriklerine ve frekanslarına genel olarak bakıldığında MTÖ'nün içerik bakımından matematik tarihinin matematik eğitiminde kullanılma amaçlarını kapsar nitelikte kullanılmadığı söylenebilir. Tarihsel notların, matematikçilerinin bilime katkılarının veya yaşamlarının ders kitaplarında yer almasının matematik tarihinin matematik derslerinden kullanılmasını hedeflenen noktaya getirmemektedir (Fried, 2001; Swetz, 1997). Çeşitli araştırmalar (Alpaslan ve Işıksal Bostan, 2016; Gulikers ve Blom, 2001; Swetz 1997) öğrenme, kavrama ve öğrencilere tarihî bir bakış açısı kazandırabilmede matematikçilerin hayatlarından ve ortaya koydukları çalışmalardan ders kitaplarında söz etmenin büyük payı olduğunu ifade etmişlerdir ve öğretimi zenginleştirmenin en işe yarar yolu matematikçilerin geçmişte üzerinde çalıştıkları problemlerin sınıf ortamına taşınmasıdır. Söz konusu görüşler göz önünde bulundurulduğunda, ders kitaplarında hali hazırdaki MTÖ kullanım yollarına alternatifler sunulmasının gerekli olduğu söylenebilir. Ayrıca matematik tarihine ait kavramların matematiksel ilişkilendirmelerle verilmesi ve öğretilmeye çalışılan konuyla bağlantısı kurularak öğretimin bir parçası haline getirilmesi gerekmektedir. Örneğin, 6. Sınıf ders kitabında "çoklukları karşılaştırmada oran kullanır ve oranı farklı biçimlerde gösterir" kazanımının öğretildiği bölümde altın orandan söz edilebilir. Buradan hareketle örnek resim ve uygulamalarla altın oranın, 1170'li yıllarda yaşamış İtalyan Matematikçi Leonardo Fibonacci'nin kendisine sorulan basit bir tavşan probleminden esinlenerek ortaya koyduğu sayı dizisinden hareketle bulunduğunun ifade edilmesi, şüphesiz ki tavşan probleminin de çözüldüğü bir öğrenme ortamında dikkate değer bir ilgiye sebep olacaktır. Bu bağlamda matematik tarihinin hem ders kitaplarında hem matematik dersi kapsamında işlevi yeniden inşa edilerek etkili bir hale getirilmesi sağlanmalıdır.

Ders kitaplarında kullanılan MTÖ'nün kullanım yollarına göre sınıflandırılması incelendiğinde ögelerin büyük bölümünün tarihsel ufak parçalar, 2'sinin deneysel matematik etkinlikleri, 1'inin öğrenciyi araştırmaya yönlendiren internet taraması, 1'inin mekanik araçlar, 1'inin ise birincil kaynaklar şeklinde kullanıldığ 1 görülmektedir. Tarihsel problemlere, tarihsel metinlere bağll araştırma problemlerine, oyunlara, film $v b$ görsellere, okul dışı deneyimlere, birincil kaynaklara ve matematikçilerin yaptıkları hatalara ise hiç değinilmemiştir. Buradan hareketle ders kitaplarında kullanılan MTÖ'nün sayısının az, niteliğinin düşük olmasının yanında çeşitliliğinin yetersiz olduğu belirtilebilir. Matematik tarihine bağlı gerçekleştirdiği çalş̧masında Clark (2012), öğretimde matematik tarihi etkinliklerine yer verilmesinin öğrencilerde farklı matematiksel bakış açıları geliştirdiğini belirtmiştir. Öğrencilerin farklı bakış açıları ortaya koymalarına yardımcı olmanın, onların ayrıca bilişsel gelişimlerini de desteklediği (Cheung, 2014) göz ardı edilemez bir gerçektir. Bu açıdan alanda yapılan çalışmalara (Bidwell, 1993; Cheung, 2014; Furinghetti, 2019) paralel olarak, ulaşılan MTÖ'nün öğrencilerin bilişsel gelişimlerine katkılarının az olduğu söylenebilir.

Kitaplardaki konumlarına göre MTÖ incelendiğinde genellikle konuya giriş kısmında olmak üzere konu içerisinde ve konu sonunda yer aldıkları görülmüştür. Bu durumda MTÖ’ye öğrencilerin daha çok dersin giriş bölümünde dikkatlerinin çekilmesi ve derse ilişkin güdülenmelerinin sağlanması amacıyla konunun giriş kısmında daha fazla yer verildiği düşünülebilir. Gerçekten de tarihsel öğelerin öğrencilerin matematik dersine karşı tutumlarında ve derse ilişkin motivasyonlarında olumlu etkilerinin olduğunu söyleyen pek çok çalışma (Ay, 2019; Ersoy, 2015; Kaşıķ̧ı, 2015; Mersin, 2019) mevcuttur. Hem kitaplardaki konumları elde edilen bulgular Baki ve Bütüner (2013) ve Erdoğan ve arkadaşları (2015) konuyla ilgili yaptıkları çalışmalarla paralellik gösterirken, İncikabı ve arkadaşları (2018) çalışmasından ayrılmaktadır. İncikabı ve arkadaşları (2018) incelediği ders kitaplarında MTÖ’ye konu içerisinde daha fazla yer verildiği görülmüştür. Öğrenme alanlarına göre yapılan 
sınıflandırmada ise sayılar ve işlemler öğrenme alanına 12, geometri ve ölçme alanına 8, veri işlemeye ilişkin 6 ve olasılığa ilişkin 2 tane matematik tarihi öğesiyle karşılaşılırken, Cebir konusunda incelenen kitapların hiçbirinde matematik tarihine yönelik bir nota rastlanmamıştır. Bunun sebebinin ortaokul matematik dersi öğretim programında yer alan sayılar, işlemler ve geometri konularının tarihle ilişkilendirilmesinin öğrenci seviyesine daha uygun olması söylenebilir. Yine de Cebir'in babası olarak nitelendirilen (Fazlığlu, 1997) Harezmî'den (öl. 303) veya “ $x$ ” işaretinin ortaya çıkışından öğrencilere söz edilebilir. Nitekim 2018 öncesinde kullanılan ders kitaplarını inceledikleri çalışmalarında İncikabı ve arkadaşları (2018) ve Erdoğan ve arkadaşları (2015) 6. Sınıf ders kitabında Cebir öğrenme alanından 3 tane MTÖ’ye yer verildiğini ifade etmişlerdir.

\section{5. Öneriler}

Söz konusu sonuçlar ışı̆̆ında matematik eğitiminde kullanılmasının öneminin pek çok çalışmalarla vurgulanmış olmasına rağmen matematik tarihine eğitim sürecinde yeterince ve nitelikli şekilde yer verilmediğ $i$ söylenebilir. Bu çalışma sadece ortaokul ders kitaplarında yer verilen tarihsel öğeleri niceliksel olarak inceleyen bir çalışmadır. İleride yapılacak araştırmalarda farklı öğrenme seviyelerinde kitaplar, örneklerine de yer verilerek matematik tarihi bağlamında incelenebilir.

Matematik dışı veya matematik bilimi ile ilgili tarihsel notların, matematikçilerinin bilime katkılarının veya yaşamlarının ders kitaplarında yer almasının tek başına matematik tarihinin etkililiği için yeterli olmadığı alan yazında belirtilmiştir. Matematik tarihi matematik öğretiminde veya matematik ders kitaplarında kullanılırken, birbirinden veya öğrenilecek konudan kopuk şekilde değil de çeşitli ilişkilendirilmelerle konunun bir parçası haline getirilebilir.

Matematiksel kavramların tarihi gelişimlerinin, nasıl ve hangi ihtiyaçla ortaya çıktıklarının öğrencilere keşfettirilmesi veya aktarılması, şüphesiz ki söz konusu kavramları öğrenmelerine yardımcı olacaktır. Bu kavramların kazandırılmasında salt bilgi sunulmasından ziyade, oyunlar, müze gezileri, bölgesel keşifler, drama ve grup projeleri gibi etkinliklerin kullanılması açısından ders kitapları zenginleştirilebilir.

Matematik Tarihine yönelik etkinliklere matematik derslerinde yer verilmesi gerektiği alanyazında yer almaktadır. Ancak 2018 yılında güncellenmiş ortaokul matematik dersi öğretim programında matematik tarihinden yeterli düzeyde söz edilmemesine paralel olarak matematik tarihi ögelerine ders kitaplarında da yeterli düzeyde yer verilmemiştir. Bu bağlamda son öğretim programında bu alana yönelik kazanımlara daha fazla yer verilebilir.

Matematik tarihinde öğrencilerin seviyelerine uygun olarak öğrenme ortamına taşınabilecek pek çok konu başlığı vardır. Sınıf bazında ders kitaplarında yer verilmek üzere bu çalışma kapsamında yapılan araştırma sonucunda bazı başlıklar önerilebilir:

\section{Sınıf Matematik Ders Kitabı için öneriler}

Antik Mısır matematiği, sayıların tarihçesi, kesirlerin ilk gösterimleri, Osmanlı Medreselerinde kesirlerle işlemler, Gıyasettin Cemşid, Atatürk'ün yazdığı geometri kitabı, Grafiklerin mucidi: William Playfair, Saatin İcadı ve Tarihsel Gelişimi, Atatürk'ün ölçü birimleri standartlaştırması gibi matematik tarihinin amacına kullanımını destekleyen tarihsel ögelere yer verilebilir.

\section{Sınıf Matematik Ders Kitabı için öneriler}

Roman Rakamları, Erathosthenes Kalburu, George Cantor ve Küme Kavramı, Tarih Şeridi, Ondalık Sayıları Kâşifi: Gıyaseddin Çemşîd, Altın oran ve Fibonacci, Osmanlı'da bilinmeyen kavramı, Grafiklerin mucidi: William Playfair, Atatürk’ün yazdığı geometri kitabı, Atatürk’ün ölçü birimleri standartlaştırması, Pi sayısının bulunması gibi tarihsel ögeler ders kitaplarında kullanılabilir.

\section{$\checkmark$ 7. Sınıf Matematik Ders Kitabı için öneriler}

Galileo Termometresine, sonsuzluk kavramı, Osmanlı Medreselerinde kesirler, Gauss Teoremi, Denklerin Efendisi: Ömer Hayyam, Atatürk'ün yazdığı geometri kitabı, Arıların petekleri altıgen şeklinde yapması, pi sayısının ortaya çıkması, Grafiklerin mucidi: William Playfair gibi matematik tarihi ögeleri matematik ders kitaplarında matematik kavramlarının öğretimi amacıyla kullanılabilir.

\section{Sinıf Matematik Ders Kitabı için öneriler}

Erathosthenes Kalburu, Satranç ve üslü sayılar ilişkisi, kök 2 sayısının hikayesi, Pascal ve olasılık, Harezmmi ve Cebir, Analitik Geometrinin tarihçesi, Atatürk'ün yazdığı geometri kitabı, Thales Teoremi, Ressam Echer ve Mısır Piramitleri gibi matematik tarihi ögelerine ortaokul matematik ders kitaplarında yer verilebilir. 


\section{Kaynaklar / References}

Agoshko, V. I. \& Puel Jp. (2009). Mathematical models of life support systems, Encyclopediaof Life Support Systems. United Kingdom: Oxford Eolss Publisher.

Albayrak, Ö. (2011). Matematik tarihiyle işlenmiş olan derslerin matematik özyeterlik algisina ve matematik başarısına etkisi (Yayınlanmamış yüksek lisans tezi). Boğaziçi Üniversitesi, Fen Bilimleri Enstitüsü, İstanbul.

Ay, B. (2019). Matematik tarihi tabanlı modelleme etkinlikleri ile 7. sinıf ögrencilerinin negatif tam sayllar konusundaki anlamalarının incelenmesi (Yayınlanmamış yüksek lisans tezi). Orta Doğu Teknik Üniversitesi, Sosyal Bilimler Enstitüsü, Ankara.

Baki, A. (2006). Kuramdan uygulamaya matematik eğitimi, Trabzon: Derya Kitabevi.

Baki, A. ve Bütüner, S. Ö. (2010, Eylül). Matematik tarihi etkinlikleriyle zenginleştirilmişs sınıf ortamından yansımalar. IX. Ulusal Fen Bilimleri ve Matematik Eğitimi Kongresi'nde sunulan bildiri, İzmir.

Baki, A., \& Gürsoy, K. (2018). Does using history of mathematics make sense? The views of teacher candidates. Journal of Pedagogical Research, 2(2), 78-90.

Baş, M. (2019). Historical development of mathematics and use of the history of mathematics in mathematics education. TAY Journal, 3(1), 1-22.

Başıüyük, K. (2018). Cebir ve sayılar öğretiminde matematik tarihi kullanımının başarı ve tutuma etkisi ve sınıf içi yansımalar (Yayınlanmamış Doktora Tezi). Gazi Üniversitesi Eğitim Bilimleri Enstitüsü, Ankara.

Baykul, Y. (2002). Illköğretimde matematik öğretimi 6.-8. sinıflar için, Ankara: PegemA.

Baykul, Y. (2003). İlköğretimde matematik öğretimi 1.-5. siniflar için. Ankara: PegemA.

Bidwell, J. (1993). Humanize your classroom with the history of mathematics. Mathematics Teacher, 86(6), 461464.

Burton, D. M. (2017). The history of mathematics. (S. Durmuş, Çev.). İstanbul: Nobel Yayınevi.

Bruner, J. S. (1962). On knowing: Essays for the left hand. Cambridge, MA: The Belknap Press of Harvard University Press.

Bütüner, S. Ö. (2020). An evaluation of activities based on the use of the history of mathematics as a tool. Journal of Pedagogical Research, 4(2), 139-164.

Canady, S. (1983). A study of the effects of the essential elements of instruction model on mathematics achievement, Unpublished doctoral dissertation. Northern Arizona University, Usa.

Cajori, F. (2014). Matematik tarihi. (D. İlalan, Çev.). Ankara: ODTÜ Yayıncılık.

Charles, S. (2003). Öğretmenler için Piaget ilkeleri. (G. Ülgen, Çev.). Ankara: Nobel.

Cheung, W. S. (2014). The effect on students' mathematical beliefs by integrating history of mathematics in the classroom (Unpublished Doctoral Dissertation). The Chinese University of Hong Kong, China.

Clark, K. M. (2012). History of mathematics: illuminating understanding of school mathematics concepts for prospective mathematics teachers. Educational Studies in Mathematics, 81 (1), 67-84. doi: 10.1007/s10649011-9361-y

Erdoğan, A., Eşmen, E. ve Fındık, S . (2016). Ortaokul Matematik Ders Kitaplarında Matematik Tarihinin Yeri: Ekolojik Bir Analiz. Marmara Üniversitesi Atatürk Eğitim Fakültesi Ĕgitim Bilimleri Dergisi, 42(42), 239259.

Ersoy, E. (2015). Matematik tarihi kullanımının ilkokul 4. sınıf öğrencilerinin akademik başarısı, hatırda tutma düzeyi ve motivasyonu üzerindeki etkileri (Yayınlanmamış yüksek lisans tezi). Adnan Menderes Üniversitesi, Sosyal Bilimler Enstitüsü, Aydın.

Fauvel, J. \& Van Maanen, J. (Eds.) (2002). History in mathematics education. The ICMI (International Commission on Mathematical Instruction) study. Dordrecht: Kluwer.

Fazlıŏlu, İ. (1997). "Hârizmî, Muhammed b. Mûsâ". Türkiye Diyanet Vakfi İslâm Ansiklopedisi. 16: 224-227. İstanbul: TDV Yayınları.

Furinghetti, F. (2019). History and epistemology in mathematics education, International Journal of Mathematical Education in Science and Technology, 9(2), 147-151. Doi: 10.1080/0020739X.2019.1565454

Gençkaya, Ş. (2018). Matematik eğitiminde matematik tarihinin kullanılmasının farklı bakış açılarından incelenmesi (Yayınlanmamış Doktora Lisans Tezi). Hacettepe Üniversitesi, Eğitim Bilimleri Enstitüsü. Ankara.

Göker, L. (1997). Matematik tarihi ve Türk-İslam matematikçilerinin yeri. İstanbul: MEB.

Gürsoy, K. (2010). İlkögretim matematik öğretmen adaylarının matematik tarihinin matematik ögretiminde kullanilmasına iliş̧kin inanç ve tutumlarının incelenmesi (Yayınlanmamış yüksek lisans tezi). Karadeniz Teknik Üniversitesi, Fen Bilimleri Enstitüsü, Trabzon.

Guillen, M. (2010). Dünyayı değiştiren beş denklem, matematiğin gücü ve şiirselliği. (G. Tanrı̈ver, Çev.). Ankara: Tübitak.

Hare, M. (1999). Revealing what urban early childhood teachers think about mathematics and how they teach it: Implications for practice (Unpublished doctoral dissertation). University Of North Texas, USA.

Hersh, R. (1997). What is mathematics, really? London: Jonathan Cape. 
İlhan, A. ve Aslaner, R. (2019). 2005'ten 2018'e ortaokul matematik dersi öğretim programlarının değerlendirilmesi. Pamukkale Üniversitesi Ĕgitim Fakültesi Dergisi, 46(1), 394-415.

İncıkabı, L., Kepceoğlu, İ. ve Küçükoğlu, U. (2019). Ortaokul matematik ders kitaplarında yer verilen matematik tarihi içeriklerinin incelenmesi. Pamukkale Üniversitesi Eğitim Fakültesi Dergisi, 45 (45), 144-158.

Jankvist, U. T. (2009). A categorization of the "whys" and "hows" of using history in mathematics education. Educational Studies in Mathematics, 71(3), 235-261.

Ju, M. K., Moon, J. E. \& Song, R. J. (2016). History of mathematics in Korean mathematics textbooks: Implication for using ethnomathematics in culturally diverse school. International Journal of Science and Mathematics Education, 14(7), 1321-1338.

Karakuş, F. (2009). Matematik tarihinin matematik öğretiminde kullanılması: Karekök hesaplamada Babil metodu. Necatibey Ĕgitim Fakültesi Elektronik Fen ve Matematik Ĕ̈itimi Dergisi, 3(1), 195-206.

Kaşıkçı, M. (2015). Matematik tarihi dersinde drama yönteminin ilköğretim matematik öğretmen adaylarının bilgi, inanç ve tutumlarına etkisi (Yayınlanmamış yüksek lisans tezi). Dokuz Eylül Üniversitesi, Eğitim Bilimleri Enstitüsü, İzmir.

Krantz, S. G.(2006). An episodic history of mathematics: mathematical culture through problem solving. USA: The Mathematical Association of America.

Küçükoğlu, U. (2019). Ortaokul öğrencilerinin matematik tarihi bağlamında hazırladıkları dijital öyküler üzerine bir araştırma: Matematik nasıl doğmuştur? (Yayınlanmamış yüksek lisans tezi). Kastamonu Üniversitesi, Fen Bilimleri Enstitüsü, Kastamonu.

Lit, K. C., Siu, K. M. \& Wong, Y. N. (2001). The use of history in the teaching of mathematics: Theory, practice and evaluation of effectiveness. Education Journal, 29(1), 17-31.

McBride, C. C., \& Rollins, J. H. (1977). The effects of history of mathematics on attitudes towards mathematics of college algebra students, Journal for Research in Mathematics Education, 8(1), 57-61.

Mersin, N. ve Durmuş, S. (2018). Matematik tarihinin ortaokul matematik ders kitaplarındaki yeri. Abant Izzet Baysal Üniversitesi Eğitim Fakültesi Dergisi, 18(2), 997-1019.

Mersin, N. (2019). Ortafokul öğrencileri için matematik tarihi destekli etkinliklerin geliştirilmesi ve ögrenciler üzerindeki yansımalarının incelenmesi (Yayınlanmamış doktora tezi, Bolu Abant İzzet Baysal Üniversitesi, Eğitim Bilimleri Enstitüsü, Bolu.

Milli Eğitim Bakanlığ1 [MEB]. (2018). İlköğretim matematik dersi 6-8. Sınıflar öğretim programı ve kılavuzu, Ankara: Talim ve Terbiye Kurulu Başkanlığı.

National Council of Teachers of Mathematics [NCTM]. (2000). Principles and standards for school mathematics. Reston VA.

Özcan, D. (2014). Anadolu Lisesi öğrencilerine uygulanan matematik tarihiyle zenginleştirilmiş öğretim programının matematik başarısına etkisi (Yayınlanmamış yüksek lisans tezi). Sabahattin Zaim Üniversitesi, Sosyal Bilimler Enstitüsü, İstanbul.

Özdemir, A. Ş. \& Göktepe, S. (2012, Mart). Matematik Tarihi Etkinlikleriyle Matematik Derslerinin İlişkilendirilmesi. X. Ulusal Fen ve Matematik Eğitimi Kongresi'nde sunulan bildiri, Niğde

Özmen, H. (2004). Fen öğretiminde öğrenme teorileri ve teknoloji destekli yapılandırmacı (constructivist) öğrenme. The Turkish Online Journal of Educational Technology, 3(1), 100-111.

Russell, B. (2004). Matematiksel felsefeye giriş'ten seçmeler. (M. Özlük, Çev.). Matematik Felsefesi, ed. B. S. Gür, Ankara: Orient Yayınları.

Siu, M-K. \& Tzanakis, C. (2004). History of mathematics in classroom teaching - appetizer? Main course? Ordessert? Mediterranean Journal for Research in Mathematics Education, 3(1-2), 5-10

Sözen, S. (2013). Sinıf ve matematik öğretmenlerine göre matematik tarihinin matematik öğretimine katılması üzerine bir olgubilim çalışması (Yayınlanmamış yüksek lisans tezi). Orta Doğu Teknik Üniversitesi, Sosyal Bilimler Enstitüsü, Ankara.

Struik, D. (2011). Kısa matematik tarihi. (Y. Silier, Çev.), İstanbul: Doruk Yayıncılık

Tan Şişman, G., Kirez, B. (2018). History of mathematics in the turkish middle school mathematics curriculum and textbooks. Cukurova University Faculty of Education Journal, 47(1), 188-215.

Thomaidis, Y. \& Tzanakis, C. (2009, February). The implementation of the history of mathematics in the new curriculum and textbooks in Greek secondary education. Paper prensented at the Congress of the European Society for Research in Mathematics Education, 2801-2810.

Tokay, E. (2019). Sayılar ve işlemler ile bazı geometrik kavramların öğretiminde matematik tarihi kullanımının, ilkokul 4. sınıf öğrencilerinin akademik başarısına etkisi (Yayınlanmamış yüksek lisans tezi). Karamanoğlu Mehmetbey Üniversitesi, Fen Bilimleri Enstitüsü, Karaman.

Tözlüyurt, E. (2008). Sayılar öğrenme alanı ile ilgili matematik tarihinden seçilen etkinliklerle yapılan dersler hakkında lise son sınıf ögrencilerinin görüşleri (Yayınlanmamış yüksek lisans tezi). Gazi Üniversitesi, Eğitim Bilimleri Enstitüsü, Ankara.

Tzanakis, C. \& Arcavi, A. (2000). Integrating history of mathematics in the classroom: An analytic survey in Fauvel and Van Maanen (Eds.). History in Mathematics Education: The ICMI Study (pp. 201-240). Dordrecht: Kluwer. 
Varol, G. B. (2019). Sayllar ve işlemler öğrenme alanında matematik tarihi entegre edilmiş matematik ögretiminin başarıya etkisi (Yayınlanmamış yüksek lisans tezi). Adnan Menderes Üniversitesi, Sosyal Bilimler Enstitüsü, Aydın.

Vygotsky, L. S. (1985). Düşünce ve dil. (S. Koray, Çev.). İstanbul: Sistem Yayınları.

Yenilmez, K. ve Uysal E. (2007). İlköğretim öğrencilerinin matematiksel kavram ve sembolleri günlük hayatla ilişkilendirebilme düzeyi. Ondokuz Mayıs Üniversitesi Ĕ̌itim Fakültesi Dergisi, 24(2007), 88-89.

Yenilmez, K. (2011). Matematik öğretmen adaylarının matematik tarihi dersine ilişkin düşünceleri. Pamukkale Üniversitesi Eğitim Fakültesi Dergisi, 30(2), 79- 90.

Yıldırım, A . (1996). Disiplinlerarası öğretim kavramı ve programlar açısından doğurduğu sonuçlar. Hacettepe Üniversitesi Eğitim Fakültesi Dergisi, 12(12), 89-94.

Yıldırım, A. ve Şimşek, H. (2013). Sosyal bilimlerde nitel araştırma yöntemleri (9. Baskı). Ankara: Seçkin Yayıncilik.

\section{Ekler:}

Ek 1. İncelenen ders kitaplarında ulaşılan Matematik Tarihi Öğeleri (MTÖ)

\begin{tabular}{|c|c|c|c|c|c|}
\hline & Sinif & Ünite & Sayfa & Konu & İçerik \\
\hline MTÖ 1 & 5 & Ünite 1 & 63 & Üslü İfadeler & Bakterilerin İlk Kez 17. yy'da kullanıldığ \\
\hline MTÖ 2 & 5 & Ünite 1 & 21 & $\begin{array}{l}\text { Sayı ve Şekil } \\
\text { Örüntüleri }\end{array}$ & Tarihi Yapılardaki Desenler ve Örüntüler \\
\hline MTÖ 3 & 5 & Ünite 2 & 87. & $\begin{array}{l}\text { Tam Sayılı ve Bileşik } \\
\text { Kesirler }\end{array}$ & Para Birimleri ve Tarihi Para resimleri \\
\hline MTÖ 4 & 5 & Ünite 3 & 130. & Ondalık Gösterimler & Atletizmde Dünya Rekorları \\
\hline MTÖ 5 & 5 & Ünite 4 & 199. & Üçgen ve Dörtgenler & $\begin{array}{l}\text { Baklava Sözcüğünün Türkçe Kökeni ve Baklavanın } \\
\text { Tarihteki Yeri }\end{array}$ \\
\hline МTÖ 6 & 5 & Ünite 5 & 216 & Veri İşleme & Osmanlı Devletinde Meclisi Mebusan'ın Üye Dağılımı \\
\hline МTÖ 7 & 5 & Ünite 5 & 225 & Veri Yorumlama & Devlet İstatistik Enstitüsü’nün 1926’da Kurulduğu \\
\hline МTÖ 8 & 5 & Ünite 5 & 235 & Veri Toplama & Çanakkale Savaşıyla İlgili Problem \\
\hline MTÖ 9 & 5 & Ünite 5 & 247 & Veri Toplama & 15 Temmuz ve Ömer Halis Demir İle İlgili Örnek \\
\hline MTÖ 10 & 5 & Ünite 5 & 248 & Veri Toplama & Türk Kadınlarına Seçme Seçilmenin Tanınması \\
\hline MTÖ 11 & 5 & Ünite 5 & 249 & Veri Toplama & İlk Televizyonun Bulunması \\
\hline МTÖ 12 & 5 & Ünite 6 & 259 & Alan Ölçme & Plazma Teknolojisinin Bulunması \\
\hline МTÖ 13 & 6 & Ünite 1 & 18 & Üslü Sayılar & Satrancın Bulunmasıyla İlgili Bilgiler \\
\hline МTÖ 14 & 6 & Ünite 1 & 29 & Problem Çözme & Matematiğin Tarihten Bu Yana Sürekli Gelişimi \\
\hline MTÖ 15 & 6 & Ünite 2 & 85 & Mutlak Değer & $\begin{array}{l}\text { Mutlak Konumun Tarih Çizelgesi Yardımıyla } \\
\text { Anlatılması }\end{array}$ \\
\hline MTÖ 16 & 6 & Ünite 3 & 174 & Oran & Naim Süleymanoğlu’nun Kırdığı Rekor \\
\hline МTÖ 17 & 6 & Ünite 6 & 306 & Çember Ve Daire & Pi Sayısın Nasıl Bulunduğu \\
\hline MTÖ 18 & 7 & Ünite 4 & 160 & Yüzdeler & $\begin{array}{l}\text { Türk Bayrağının Boyunun ve Eninin Oranları ve Bu } \\
\text { Oranların Netleşme Tarihi }\end{array}$ \\
\hline МТÖ 19 & 7 & Ünite 5 & 173 & Doğrular ve Açılar & Atatürk'ün Geometri Kitabı \\
\hline MTÖ 20 & 7 & Ünite 5 & 229 & Cember ve Daire & Tekerleğin Bulunması \\
\hline MTÖ 21 & 7 & Ünite 5 & 188 & Çokgenler & Tangramın Bulunma Hikâyesi \\
\hline MTÖ 22 & 8 & Ünite 1 & 11 & Çarpanlar ve Katlar & $\begin{array}{l}\text { İlk Hesap Makinesinin 1645'te Pascal Tarafından İcat } \\
\text { Edilmesi }\end{array}$ \\
\hline MTÖ 23 & 8 & Ünite 1 & 12 & Çarpanlar ve Katlar & Sümerlerin Matematikte $60{ }^{\prime} l_{1}$ Say1 Sistemi Kullanması \\
\hline МTÖ 24 & 8 & Ünite 2 & 58 & Kareköklü İfadeler & Pisagor’un Kök 2'yi Tanımlama Biçimi \\
\hline МTÖ 25 & 8 & Ünite 3 & 103 & Olasılık ve Cebir & Olasılık Kavramının Doğuşu \\
\hline МTÖ 26 & 8 & Ünite 6 & 263 & Geometri ve Ölçme & İngiltere'deki Arundel Kalesinin Yapısı Ve Tarihi \\
\hline МTÖ 27 & 8 & Ünite 6 & 278 & Geometrik Cisimler & Türklerin Davul Kullanımı \\
\hline
\end{tabular}

Ek 2. Ortaokul Matematik Dersi Öğrenme Programına Göre 5. Sınıf Seviyesine Uygun Olarak Önerilebilecek Matematik Tarihi Ögeleri (ÖMTÖ)

\begin{tabular}{|c|c|c|}
\hline \multicolumn{3}{|c|}{ 1. Ünite Konuları } \\
\hline 1 & Doğal Sayılar & ÖMTÖ5.1 - Antik Mısır Matematiği \\
\hline 2 & Doğal Sayılarla İşlemler & ÖMTÖ5.2 - Doğal Sayılar ve İşlemlerin Kısa Tarihçesi \\
\hline \multicolumn{3}{|c|}{ 2. Ünite Konuları } \\
\hline 3 & Kesirler & ÖMTÖ5.3 - Kesirlerin Gösterimine Dair Tarihsel Notlar \\
\hline 4 & Kesirlerle İşlemler & ÖMTÖ5.4 - Osmanlı Medreselerinde Kesirlerle İşlemler \\
\hline \multicolumn{3}{|c|}{ 3. Ünite Konuları } \\
\hline 5 & Ondalık Gösterim & ÖMTÖ5.5 - Gıyaseddin Çemşîd Ve Matematik \\
\hline 6 & Yüzdeler & ÖMTÖ5.6 - Yüzde İşaretinin İlk Kullanımı \\
\hline
\end{tabular}


Ek 2'nin devamı

\section{4. Ünite Konuları}

7 Temel Geometrik Kavramlar

8 Üçgenler Ve Dörtgenler

5. Ünite Konuları

9 Veri Toplama Ve Değerlendirme

10 Uzunluk Ve Zaman Ölçme

6. Ünite Konuları

11 Alan Ölçme

12 Geometrik Cisimler
ÖMTÖ5.7 - Atatürk'ün Yazdığı Geometri Kitab1

ÖMTÖ5.7 - Atatürk'ün Yazdığı Geometri Kitabı

ÖMTÖ5.8 - Grafiklerin Mucidi: William Playfair

ÖMTÖ5.9 - Saatin İcadı Ve Tarihsel Gelişimi

ÖMTÖ5.10 - Atatürk'ün Ölçü Birimleri Standartlaştırması

ÖMTÖ5.11 - Weldi - Blundell Prizmas1

Ek 3. Ortaokul Matematik Dersi Öğrenme Programına Göre 6. Sınıf Seviyesine Uygun Olarak Önerilebilecek Matematik Tarihi Ögeleri (ÖMTÖ)

\section{1. Ünite Konuları}

1 Doğal Sayılarla İşlemler

2 Çarpanlar Ve Katlar

3 Kümeler

2. Ünite Konuları

4 Tam Sayılar

5 Kesirlerle İşlemler

3. Ünite Konuları

6 Ondalık Gösterim

7 Oran

4. Ünite Konuları

8 Cebirsel İfadeler

9 Veri Toplama Ve Değerlendirme

10 Veri Analizi

5. Ünite Konuları

11 Açılar

12 Alan Ölçme

6. Ünite Konuları

13 Çember

14 Geometrik Cisimler
ÖMTÖ6.1 - Romen Rakamları

ÖMTÖ6.2 - Erathostenes Kalburu

ÖMTÖ6.3 - George Cantor'un Sezgisel Küme Kavramı

ÖMTÖ6.4 - Milat Kavramı ve Tarih Șeridi

ÖMTÖ6.5 - Osmanlı Medreselerinde Kesirlerle İşlemler

ÖMTÖ6.6 - Ondalık Sayıları Kâşifi: Gıyaseddin Çemşîd

ÖMTÖ6.7 - Altın Oran ve Fibonacci

ÖMTÖ6.8 - Osmanlıda "x"

ÖMTÖ6.9 - Grafiklerin Mucidi: William Playfair

ÖMTÖ6.9 - Grafiklerin Mucidi: William Playfair

ÖMTÖ6.10 - Atatürk'ün Yazdığı Geometri Kitab1

ÖMTÖ6.11 - Atatürk'ün ölçü birimleri standartlaştırması

ÖMTÖ6.12 - Pi Sayısının Bulunması

ÖMTÖ6.13 - Weldi-Blundell prizması

Ek 4. Ortaokul matematik dersi öğrenme programına göre 7. sınıf seviyesine uygun olarak önerilebilecek matematik tarihi ögeleri (ÖMTÖ)
1. Ünite Konuları
1 Tam Sayılarla İşlemler
2. Ünite Konuları
2 Rasyonel Sayilar
3 Rasyonel Sayılarla İşlemler
3. Ünite Konuları
4 Cebirsel İfadeler
5 Eşitlik Ve Denklem
4. Ünite Konuları
6 Oran Orant1
7 Yüzdeler
5. Ünite Konuları
8 Doğrular ve Açılar
9 Çokgenler
10 Çember ve Daire
6. Ünite Konuları
11 Veri Analizi
12 Cisimlerin Farkl1 Yönlerden
ÖMTÖ7.1 - Galileo Termometresine ilişki bir problem
ÖMTÖ7.2 - Payda Neden “0” olmaz? Sonsuzluk Kavramı
ÖMTÖ7.3 - Osmanlı Medreselerinde Kesirlerle İşlemler
ÖMTÖ7.4 - Küçük Gauss'un Hikâyesi ve Teoremi
ÖMTÖ7.5 - Denklemlerin Efendisi: Ömer Hayyam
ÖMTÖ7.6 - Altın Oran ve Fibonacci
ÖMTÖ7.7 - Yüzde İşaretinin İlk Kullanımı
ÖMTÖ7.8 - Atatürk’ün Yazdığ1 Geometri Kitab1
ÖMTÖ7.9 - Arılar Matematik Biliyor
ÖMTÖ7.10 - Pi Sayısının ortaya çıkması
ÖMTÖ7.11 - Grafiklerin Mucidi: William Playfair
12 Görünümleri
ÖMTÖ7.12 - Atatürk'ün ölçü birimleri standartlaştırması 
Ek 5. Ortaokul matematik dersi öğrenme programına göre 8. sınıf seviyesine uygun olarak önerilebilecek matematik tarihi ögeleri (ÖMTÖ)

\section{1. Ünite Konuları}

1 Çarpanlar ve Katlar

2 Üslü İfadeler

2. Ünite Konuları

3 Kareköklü İfadeler

$4 \quad$ Veri Analizi

3. Ünite Konuları

$5 \quad$ Basit Olayların Olma Olasılığı

6 Cebirsel İfadeler ve Özdeşlikler

4. Ünite Konuları

7 Doğrusal Denklemler

8 Eşitsizlikler

5. Ünite Konuları

9 Üçgenler

10 Eşlik ve Benzerlik

6. Ünite Konuları

11 Dönüşüm Geometrisi

12 Geometrik Cisimler
ÖMTÖ8.1 - Erathostenes Kalburu

ÖMTÖ8.2 - Satranç ve Kral'ın Vaadi

ÖMTÖ8.3 - $\sqrt{2}$ sayısının hikâyesi

ÖMTÖ8.4 - Grafiklerin Mucidi: William Playfair

ÖMTÖ8.5 - Hilesiz Zar: Pascal

ÖMTÖ8.6 - Cebrin isim babası: Harezmî

ÖMTÖ8.7 - Analitik Geometrinin Tarihçesi ile ilgili ödev çalışması ÖMTÖ8.8 -

ÖMTÖ8.9 - Atatürk'ün Yazdığg Geometri Kitab1 ÖMTÖ8.10 - Thales Teoremi

ÖMTÖ8.11 - Matematiği Resmeden Adam: Escher ÖMTÖ8.12 - Gizemli Mimarî: Misır Piramitleri 